\title{
Osteoprotective Roles of Green Tea Catechins
}

\author{
Hsuan-Ti Huang 1,2,3,4,5, Tsung-Lin Cheng 1,5,6 , Sung-Yen Lin 1,2,3,4, Cheng-Jung Ho 1,2,3, \\ Joanna Y. Chyu ${ }^{7}$, Rong-Sen Yang ${ }^{8}(\mathbb{D})$, Chung-Hwan Chen $1,2,3,4,5,9,10, *(\mathbb{D}$ \\ and Chwan-Li Shen 11,12,*
}

1 Orthopaedic Research Center, Kaohsiung Medical University, Kaohsiung 80701, Taiwan; hthuang@kmu.edu.tw (H.-T.H.); junglecc@gmail.com (T.-L.C.); tony8501031@gmail.com (S.-Y.L.); rick_free@mail2000.com.tw (C.-J.H.)

2 Department of Orthopedics, Kaohsiung Medical University Hospital, Kaohsiung Medical University, Kaohsiung 80701, Taiwan

3 Departments of Orthopedics, College of Medicine, Kaohsiung Medical University, Kaohsiung 80701, Taiwan

4 Department of Orthopedics, Kaohsiung Municipal Ta-Tung Hospital, Kaohsiung 80145, Taiwan

5 Regeneration Medicine and Cell Therapy Research Center, Kaohsiung Medical University, Kaohsiung 80701, Taiwan

6 Department of Physiology, College of Medicine, Kaohsiung Medical University, Kaohsiung 80701, Taiwan

7 School of Medicine, University of Texas Medical Branch, Galveston, TX 77555, USA; jychyu@utmb.edu

8 Department of Orthopedics, National Taiwan University Hospital, Taipei 100229, Taiwan;

rsyang@ntuh.gov.tw

9 Institute of Medical Science and Technology, National Sun Yat-Sen University, Kaohsiung 80424, Taiwan

10 Department of Healthcare Administration and Medical Informatics, Kaohsiung Medical University, Kaohsiung 80701, Taiwan

11 Department of Pathology, Texas Tech University Health Sciences Center, Lubbock, TX 79430, USA

12 Center of Excellence for Integrative Health, Texas Tech University Health Sciences Center, Lubbock, TX 79430, USA

* Correspondence: hwan@kmu.edu.tw (C.-H.C.); leslie.shen@ttuhsc.edu (C.-L.S.); Tel.: +886-7-3208209 (C.-H.C.); +1-(806)-743-2815 (C.-L.S.)

Received: 27 September 2020; Accepted: 12 November 2020; Published: 16 November 2020

\begin{abstract}
Osteoporosis is the second most common disease only secondary to cardiovascular disease, with the risk of fracture increasing with age. Osteoporosis is caused by an imbalance between osteoblastogenesis and osteoclastogenesis processes. Osteoclastogenesis may be enhanced, osteoblastogenesis may be reduced, or both may be evident. Inflammation and high reactive oxygen enhance osteoclastogenesis while reducing osteoblastogenesis by inducing osteoblast apoptosis and suppressing osteoblastic proliferation and differentiation. Catechins, the main polyphenols found in green tea with potent anti-oxidant and anti-inflammatory properties, can counteract the deleterious effects of the imbalance of osteoblastogenesis and osteoclastogenesis caused by osteoporosis. Green tea catechins can attenuate osteoclastogenesis by enhancing apoptosis of osteoclasts, hampering osteoclastogenesis, and prohibiting bone resorption in vitro. Catechin effects can be directly exerted on pre-osteoclasts/osteoclasts or indirectly exerted via the modulation of mesenchymal stem cells (MSCs)/stromal cell regulation of pre-osteoclasts through activation of the nuclear factor kB (RANK)/RANK ligand (RANKL)/osteoprotegerin (OPG) system. Catechins also can enhance osteoblastogenesis by enhancing osteogenic differentiation of MSCs and increasing osteoblastic survival, proliferation, differentiation, and mineralization. The in vitro effects of catechins on osteogenesis have been confirmed in several animal models, as well as in epidemiological observational studies on human subjects. Even though randomized control trials have not shown that catechins provide anti-fracture efficacy, safety data in the trials are promising. A large-scale, placebo-controlled, long-term randomized trial with a tea regimen intervention of optimal duration is required to determine anti-fracture efficacy.
\end{abstract}


Keywords: green tea extract; osteoprotection; apoptosis; antioxidant; inflammation; mesenchymal stem cells

\section{Osteoporosis}

Osteoporosis is a disease that causes reduced bone density and quality. Bones become fragile and more porous, and as a result the risk of fracture is greatly increased. As a result, osteoporosis is a global problem with increasing laboratory significance. Bone mineral density (BMD) and quality decide bone strength. Bone quality is determined by bone architecture, turnover, damage accumulation, matrix mineralization, and collagen composition [1]. The lifetime risk of fragility fractures is around $40 \%$, including forearm, vertebral, and hip fractures, similar to the risk for cardiovascular disease [2]. One in two women and one in three men aged greater than 60 years will have an osteoporosis-related fragility fracture that may increase the monetary burden by USD131.5 billion by 2050 [3-5].

Bone has dynamic turnover through a remodeling process controlled by osteoclasts, osteoblasts, and osteocytes. Mesenchymal stem cells (MSCs) in bone marrow can differentiate into osteoblastic linage cells containing osteoblasts and osteocytes [6], whereas osteoclasts are derived from the monocyte/macrophage linage of hematopoietic stem cells [7]. The metabolic activities of these cells are regulated by local and systemic stimuli comprising mechanical, immunological, and hormonal factors. An imbalance of regulatory factors is closely associated with osteoporosis. An imbalance between osteoclastogenesis (bone resorption) and osteoblastogenesis (bone formation) during remodeling, which causes enhanced bone resorption with or without decline in bone formation, remains the main cause of osteoporosis [8].

\subsection{Molecular Regulation in Osteoporosis}

The canonical Wnt signaling is the main pathway regulating osteoblastogenesis, including osteoblastic differentiation, proliferation, maturation, and activity. Wnt signaling is associated with an increase of intracellular and intranuclear translocation of $\beta$-catenin levels [9]. Both runt-related transcription factor 2 (Runx2) [10] and Osterix (Osx) [11], also known as SP7 in human [12], control osteoblastic differentiation of MSCs [9]. Osteogenic differentiation can be enhanced by bone morphogenetic proteins (BMPs), a member of the transforming tumor growth factor (TGF) superfamily, through increasing Runx2 expression, which in turn raises Osx/SP7 expression [13]. Conversely, Wnt signaling inhibits adipogenesis by stimulating Runx 2 and inhibiting CCAAT-enhancer binding protein $\alpha(\mathrm{C} / \mathrm{EBP} \alpha)$ [13]. Excessive oxidative stress may cause increased reactive oxygen species (ROS), increased phosphorylation of p53 and p66, and decreased expression of $\beta$-catenin, leading to apoptosis of osteoblasts [14-17]. In addition, the increase in osteoblast apoptosis is a possible mechanism for the reduced bone-forming ability of senescent bone [18].

The mononuclear cell precursors of the monocyte/macrophage lineage of hematopoietic stem cells differentiate into osteoclasts, which are large multinucleated cells. Osteoclastogenesis is mainly controlled by macrophage-colony stimulating factor (M-CSF) and by receptor activation of the nuclear factor kB (RANK)/RANK ligand (RANK-L)/osteoprotegerin (OPG) system [7]. Mature multinucleated osteoclasts lead to bone resorption and initiation of bone remodeling [7]. Age-dependent enhancement in osteoblast-regulated osteoclastogenesis has shown decreased OPG expression and augmented expression of RANKL and M-CSF in stromal/osteoblastic cells of the elderly $[19,20]$. Inflammatory cytokines, including IL-1, TNF $\alpha$, IL-6, and IL-17, enhance osteoclastogenesis and prohibit the differentiation and function of osteoblasts. Moreover, interferon (IFN)- $\gamma$, IL-10, IL-4, and IL-12 prohibit osteoclastogenesis, while IL-4 enhances osteoblast migration and proliferation and inhibits osteoblast differentiation [13]. 


\subsection{Oxidative Stress is Related to Osteoporosis}

ROS surge is one of the leading causes of osteoporosis during bone aging. An increase in oxidative stress or chronic inflammation, as shown by excessive reactive oxygen species (ROS), usually causes injury to DNA, protein, and lipids and promotes the progression of osteoporosis [21-24]. Apoptosis of osteoblasts and osteocytes with decreased osteoblast count can be induced by oxidative stress due to the activation of nuclear transcription factor $\mathrm{kB}(\mathrm{NF}-\mathrm{kB})$ and extracellular signal-regulated kinases (ERK) signaling pathways [25], which represses the bone formation rate via $W n t / \beta$-catenin signaling pathways in osteoblastogenesis [26]. ROS is involved in bone resorption through direct bone degradation by osteoclast-generated superoxide or through enhancement of osteoclast differentiation and function $[22,23,27-31]$.

Age-dependent bone loss is associated with reduced osteoblast numbers, enhanced apoptosis of osteoblasts and osteocytes, and decreased rate of bone formation [32-34]. Osteoporosis-related fragility fractures are noted in a murine model of premature aging and are characteristic of oxidative stress [35]. In estrogen-deficient females, elevated ROS and promoted phosphorylation of p66shc and p53 proteins that enhance production of mitochondrial ROS and cell apoptosis were found [14]. Previous human studies have also indicated a reverse relationship between the level of ROS and level of BMD. Since oxidative stress can cause bone loss, decreasing oxidative stress through antioxidants could be a possible strategy to decrease bone loss for osteoporosis prevention. Therefore, regulation of excessive oxidative stress could be a potential target for the management of osteoporosis. The bone healthy effects of antioxidant have also been shown in human studies [15,16]. Green tea catechins are potent antioxidants that have been extensively studied for their joint and muscle protective effects [36]. In this review, we examine the effects of green catechins on bone in the literature.

\section{Catechins}

Tea, brewed from the dried leaves of Camellia sinensis, is a common drink. In 2010, global consumption of tea was 4.52 million tons. Most of the teas are black tea and green tea [37]. Catechins $\left(3,3^{\prime}, 4^{\prime}, 5,7\right.$ - pentahydroxyflavan), which account for more than $80 \%$ of green tea polyphenols, are derived from flavan-3-ol. (-)-epicatechin (EC), (-)-epicatechin gallate (EGC), (-)-epigallocatechin (EGC) and (-)-epigallocatechin gallate (EGCG) are the main types of catechins [38]. EGCG possesses the most potent antioxidant and free radical scavenging abilities $[39,40]$. Thus, many benefits of green tea come from the free radical scavenging activity and antioxidant effects of catechins [36,41-51].

\subsection{In Vitro Effect of Catechins}

The antiresorptive properties of bioactive components in green tea can enhance apoptosis of osteoclasts, hamper osteoclastogenesis, and prohibit bone resorption in vitro. Effects can be directly exerted on pre-osteoclasts/osteoclasts or via the modulation of MSCs/stromal cell regulation of pre-osteoclasts. EGCG treatments have been shown to increase apoptosis of osteoclast-like multinucleated cells through a Fenton reaction, whereas osteoblasts were spared from apoptosis [52]. Yun et al. reported EGCG $(20 \mu \mathrm{M})$-decreased mRNA expression of MMP-9, but not MMP-13, and -2 in murine calvarial primary osteoblastic cells. Moreover, in the co-culture system, EGCG significantly prohibited osteoclast formation at this concentration. The authors indicated that EGCG may decrease alveolar bone resorption in periodontal diseases by prohibiting MMP-9 expression in osteoblasts and osteoclastogenesis [53]. Oka et al. found activities of MMP-9 and MMP-2 decline in EGCG (10 and $100 \mu \mathrm{M}$ )-treated rat pre-osteoclast cell cultures, while EGCG prohibits osteoclastogenesis by MMPs inhibition. In addition, theaflavin-3,3'-digallate (TFDG), the polyphenol found in black tea, suppressed actin ring formation more significantly than EGCG [54]. Tokuda et al. reported EGCG decreases bone resorption by suppression of IL-6 secretion [55] or through suppressing the activation of p44/p42 MAP kinase [56] via osteoblastic linage cell regulation. EGCG represses osteoclastic differentiation via downregulation of the RANKL-induced expression of the nuclear 
transcription factor of activated $\mathrm{T}$ cells $\mathrm{c} 1$, subsequently inhibiting osteoclastogenesis and causing decreased bone resorption [57,58]. Lin et al. found EGCG, 10-100 $\mu \mathrm{M}$, decreased the RANKL-induced osteoclastogenesis and pit formation in monocyte, RAW 264.7 cells, and primary bone marrow macrophage (BMM) cells via the inhibition of RANKL-induced NF-kB transcriptional activity and nuclear translocation [59]. Chen et al. compared the effects of EC, ECG, EGC, and EGCG at a concentration of $1 \mu \mathrm{M}$, the approximate concentration found in a cup of tea, to concentrations of $10 \mu \mathrm{M}$ and $100 \mu \mathrm{M}$, in murine bone marrow pluripotent mesenchymal cells, D1. EGCG was shown to increase mRNA expression of OPG [60]. Chen et al. found that EGCG at low concentrations $(1$ and $10 \mu \mathrm{M})$ decreases RANKL/OPG ratio, and both mRNA expression and protein secretion then decrease osteoclastogenesis via tartrate resistant acid phosphatase (TRAP) (+) stain osteoclasts and TRAP activity by the RANK/RANKL/OPG pathway in co-culture of ST2 feeder cells and RAW 264.7 cells [61].

EGCG also regulate RANK/RANKL/OPG pathway in osteoblast, MC3T3-E1 [62] and primary osteoblastic cells isolated from newborn mouse calvariae [63] via prostaglandin E2 (PGE2). EGCG treatment decreased LPS-induced expression of mRNA expression of RANKL in primary osteoblasts [63] and increased mRNA expression of OPG in MC3T3-E1 [62]. Both effects were through PGE2.

The bioactive components in green tea show the beneficial effects on osteoblastogenesis via increased osteoblastic survival, proliferation, differentiation, and mineralization [37]. Chen et al. evaluated the effects of EGCG $(1$ and $10 \mu \mathrm{M})$ in D1 cells, a murine bone marrow mesenchymal cell line. EGCG at 1 and $10 \mu \mathrm{M}$ increases mRNA expression of the degradation of Runx2, Osx/SP7, osteocalcin, and alkaline phosphatase (ALP). EGCG treatment also significantly enhanced the ALP activity. Furthermore, mineralization was augmented after EGCG treatment, with the higher concentration being more effective, while a 24-h EGCG treatment hampered the proliferation of D1 cells [64]. Thus, EGCG at 1 and $10 \mu \mathrm{M}$ can enhance mRNA expression, including Runx2, BMP-2, ALP, osteocalcin, and osteonectin, ALP activity, and mineralization in human bone marrow MSCs. EGCG without antioxidant activity can also enhance mineralization of human bone marrow MSCs [65]. EGCG enhanced osteoblasts survival by decreasing the production of TNF- $\alpha$ and IL-6 [66]. EGCG, 1-5 $\mu \mathrm{M}$, induced a dose-dependent enhancement of ALP activity and mineralization in SaOS-2 cells, which are human osteoblast-like cells. However, EGCG decreased protein levels of Runx2 at a late stage, which may indicate the facilitation of osteogenic differentiation at an early stage [67]. EGCG also enhances osteoblastogenesis via the Wnt/ $\beta$-catenin signaling pathway [68].

In osteoblast-like MC3T3-E1 cells, endothelin-1 enhances production of a potent bone resorptive agent, IL-6 [69]. In MC3T3-E1 cells and primary cultured mouse osteoblasts, EGCG significantly decreases IL-6 secretion upon endothelin- 1 treatment via inhibition of the p44/p42 MAP kinase pathway, and the suppressive effect is the crosstalk between Raf- 1 and PKC in the endothelin-1 signaling pathway $[55,70]$. In osteoblasts, EGCG increased prostaglandin F2a-related vascular endothelial growth factor production by enhancing Jun N-terminal kinase, but does not affect phosphorylation of p38 MAP kinase or ERK1/2 [56,71].

MiRNAs are small non-coding endogenous RNA molecules (around 19-25 nucleotides in length), which regulate post-transcriptional gene expression [72-76]. Five miRNAs (miR-21-5p, miR-24-3p, miR-93-5p, miR-100-5p, and miR-125b-5p) were found also significantly upregulated in bone tissue from osteoporotic patients compared to controls [77]. MiR-30b-5p and miR-142-3p were significantly correlated with both total hip and femur neck BMD [78]. EGCG treatment prohibited the apoptosis in MSCs induced by hypoxia and increased the level of RUNX2, BMP-2, ALP, and PINP in MSCs via the upregulated miR-210 expression [79].

EGCG receptors have been studied for years. The 67-kDa laminin receptor (67LR) was found [80-82]. 37-kDa gene proteins are a monomeric forerunner to a 67-kDa dimmer [83]. Retinoic acid promotes the attaching of EGCG to cancer cells via enhancing the expression of 67LR [84]. Several previous studies found that the suppressive effects of EGCG on cancer cell growth 
were through the expression of 67LR [77-81]. Moreover, the anti-allergic and anti-inflammatory effects of EGCG were also via the 67LR [82-84]. After EGCG binding to 67LR, through eukaryotic translation elongation factor 1A (eEF1A), the phosphorylation of MYPT1 at Thr-696 is reduced, which stimulated myosin phosphatase, and the actin cytoskeleton is rearranged, which can inhibit cell growth. In multiple myeloma and acute myeloid leukemia, EGCG persuades apoptosis in the 67LR-expressing cells [85]. The effects of EGCG on 67LR may be the most important mechanisms for the bio-effects of EGCG (Table 1).

Table 1. In vitro effects of catechins.

\begin{tabular}{|c|c|c|}
\hline First Author, Year & Experimental Design and Treatments & Results \\
\hline Nakagawa, 2002 [52] & $\begin{array}{l}\text { Model: primary cultured Crude murine osteoclast-like } \\
\text { multinucleated cells (OCLs) } \\
\text { Treatments: EGCG }(25-100 \mu \mathrm{M}) \text { for } 24 \mathrm{~h}\end{array}$ & $\begin{array}{l}\text { EGCG treatments: } \\
\uparrow \text { apoptotic cell death of osteoclast-like multinucleated cells, } \\
\text { whereas osteoblasts affected the Fenton reaction primarily } \\
\text { involved in EGCG-induced osteoclastic cell death }\end{array}$ \\
\hline Chen, 2003 [60] & $\begin{array}{l}\text { Model: The pluripotent mesenchymal cell, D1, cloned from } \\
\text { mouse bone marrow cells } \\
\text { Treatments: EC, ECG, EGC, and EGCG at a concentration of } 1 \\
\mu \mathrm{M} \text {, the achievable concentration with one cup of tea drinking, } \\
10 \mu \mathrm{M} \text { and } 100 \mu \mathrm{M} \text { for } 24 \text { and } 48 \mathrm{~h} \text {, respectively. }\end{array}$ & $\begin{array}{l}\text { Compared to vehicle group, EGCG groups: } \\
\uparrow \text { mRNA expression of OPG }\end{array}$ \\
\hline Yun, 2004 [53] & $\begin{array}{l}\text { Model: co-culture system of mouse bone marrow cells and } \\
\text { calvarial primary osteoblastic cells } \\
\text { Treatments: EGCG }(20 \mu \mathrm{M}) \text { in the presence of sonicated } P \text {. } \\
\text { gingivalis extracts. }\end{array}$ & $\begin{array}{l}\text { EGCG treatments: } \\
\downarrow \text { expression of MMP-9 mRNA } \\
\downarrow \text { osteoclast formation }\end{array}$ \\
\hline Chen, 2005 [64] & $\begin{array}{l}\text { Model: The pluripotent mesenchymal cell, D1, cloned from } \\
\text { mouse bone marrow cells } \\
\text { Treatments: vehicle, EGCG ( } 1 \text { and } 10 \mu \mathrm{M}) \text { for } 48 \mathrm{~h}\end{array}$ & $\begin{array}{l}\text { Compared to vehicle group, EGCG groups: } \\
\uparrow \text { mRNA expression of Runx2, osterix, osteocalcin, ALP after } \\
48 \mathrm{~h} \\
\uparrow \text { ALP activity after } 4 \mathrm{~d}, 7 \mathrm{~d} \text {, and } 14 \mathrm{~d} \\
\uparrow \text { mineralization after } 2-4 \mathrm{w} \\
\downarrow \text { thymidine incorporation }\end{array}$ \\
\hline Tokuda, 2007 [56] & $\begin{array}{l}\text { Model: osteoblastic cell line MC3T3-E1 } \\
\text { Treatments: EGCG in a dose-dependent manner in the range } \\
\text { between } 1 \text { and } 100 \mu \mathrm{M}\end{array}$ & 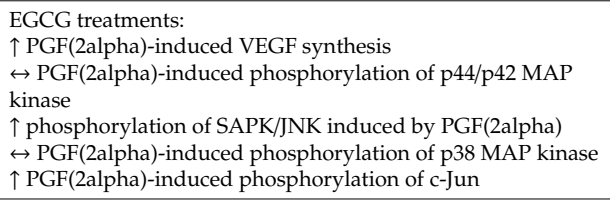 \\
\hline Morinobu, 2008 [57] & $\begin{array}{l}\text { Model: Mononuclear cells were isolated from peripheral blood } \\
\text { obtained from healthy donors. } \\
\text { Treatments: For osteoclast differentiation, the cells were cultured } \\
\text { in the presence of M-CSF }(50 \mathrm{ng} / \mathrm{mL}) \text { and RANKL }(100 \mathrm{ng} / \mathrm{mL}) \\
\text { for } 6 \mathrm{~d} \text { EGCG or other chemicals were added throughout the } \\
\text { culture, and half the medium was replaced every } 2-3 \mathrm{~d}\end{array}$ & $\begin{array}{l}\text { EGCG treatments: } \\
\downarrow \text { generation of TRAP-positive multinucleated cells, bone } \\
\text { resorption activity, and osteoclast-specific gene expression } \\
\downarrow \text { expression of nuclear factor of activated T cells c1 (NF-ATc1), } \\
\text { but not of NF-KB, c-Fos, and c-Jun } \\
\leftrightarrow \text { cell viability }\end{array}$ \\
\hline Takai, 2008 [66] & $\begin{array}{l}\text { Model: osteoblast-like MC3T3-E1 cells; primary-cultured } \\
\text { osteoblasts were obtained from the calvaria of newborn (1 or } \\
\text { 2-day old) BALB/c mice } \\
\text { Treatments: EGCG }(0-30 \mu \mathrm{M}) \text { for } 24 \mathrm{~h}\end{array}$ & $\begin{array}{l}\text { EGCG treatments: } \\
\downarrow \text { IL-6 synthesis and IL-6 mRNA expression stimulated } \\
\text { by PDGF-BB } \\
\downarrow \text { PDGF-BB-induced phosphorylation of SAPK/JNK } \\
\leftrightarrow \text { levels of osteocalcin and osteoprotegerin in MC3T3-E1 cells } \\
\leftrightarrow \text { PDGF-BB-induced autophosphorylation of PDGF receptor } \beta \\
\leftrightarrow \text { PDGF-BB-induced phosphorylation of p44/p42 MAP kinase } \\
\text { and p38 MAP kinase } \\
\leftrightarrow \text { PDGF-BB-induced phosphorylation of Akt and p70 S6 kinase }\end{array}$ \\
\hline Tokuda, 2008 [70] & $\begin{array}{l}\text { Model: osteoblast-like MC3T3-E1 cells } \\
\text { Treatments: EGCG }(0-30 \mu \mathrm{M}) \text { for } 24 \mathrm{~h}\end{array}$ & $\begin{array}{l}\text { EGCG treatments: } \\
\downarrow \text { IL-6 synthesis stimulated by FGF-2 in a } \\
\text { dose-dependent manner } \\
\downarrow \text { FGF-2-induced phosphorylation of p44/p42 MAP kinase and } \\
\text { p38 MAP kinase }\end{array}$ \\
\hline
\end{tabular}


Table 1. em Cont.

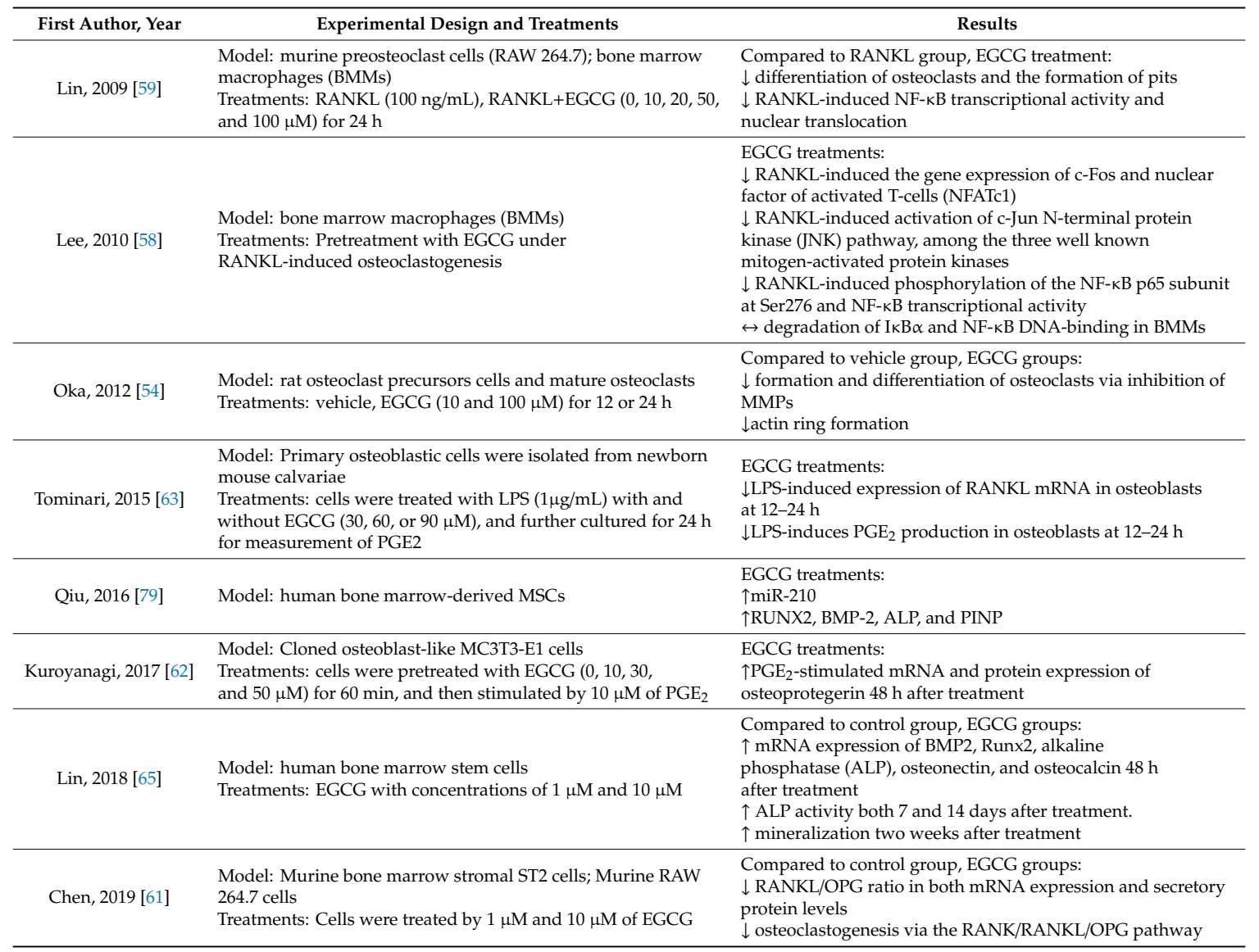

ALP, alkaline phosphatase; BMD, Bone mineral density; BMP-2, Bone Morphogenetic Protein 2; BR, buckling ratio; COX, cyclooxygenase; EGCG, epigallocatechin gallate; FHP, free hydroxyproline; GAG, glycosaminoglycan; GT, green tea; GTE, green tea extract; GTP, green tea polyphenols; iNOS, inducible nitric oxide synthase; IL-1 $\beta$, interleukin-1 $\beta$; LPS, lipopolysaccharide; MREI, molar roots exposure index; NANA, N-acetylneuraminic acid; NF- $\mathrm{KB}$, nuclear factor kappa-B; NO, nitric oxide; RANKL, Receptor activator of nuclear factor kappa-B ligand; RUNX2, Runt-related transcription factor 2; OPG, osteoprotegerin; OVX, ovariectomized; SG, salivary glands; TC, Tai Chi; TNF- $\alpha$, tumor necrosis factor- $\alpha ; \uparrow$, increase; $\downarrow$, decrease; $\leftrightarrow$, no change.

\subsection{In Vivo Effects of Catechins}

The in vitro effects of catechins on osteogenesis have been confirmed in several bone-loss models in animal studies including estrogen deficiency [86,87], aging [87,88], testosterone deficiency [88], caloric restriction [89], obesity [90], glucocorticoid-induced [91], chronic inflammation [92], and others [93].

Shen et al. demonstrated that feeding water with green tea polyphenols (GTP) consisting of EGCG, ECG, EC, EGC, and catechins, at $0.1 \%$ and $0.5 \%(w / v, w / v)$ to 14 -month-old F344xBFN1/NIA OVX and sham female rats for 16 weeks showed increased urinary ECG and EC concentrations in a dose-dependent and time dependent manner. GTP supplementation ameliorated bone loss on BMD examination and deterioration of microarchitecture on histomorphometric studies and eventually enhanced bone strength on mechanical tests [86,87]. Doses of $0.1 \%$ and $0.5 \%$ GTPs (about 1 and 4 cups of green tea of daily consumption) are safe without significant changes to serum total protein, albumin, creatinine, blood urea nitrogen, creatinine phosphokinase, aspartate transferase, alanine transferase calcium, phosphate, glucose, total bilirubin, alkaline phosphatase activity, globulin, amylase, or cholesterol [86]. Chen et al. also evaluated the in vivo effects of EGCG on estrogen deficiency by intra-peritoneal injection. They found that EGCG, $3.4 \mathrm{mg} / \mathrm{kg} / \mathrm{day}$ (about $10 \mu \mathrm{M}$ in the serum), attenuated the BMD drop and ameliorated parameters including the trabecular number, bone volume, trabecular thickness, and trabecular separation in $\mu \mathrm{CT}$ examination compared to 
non-treated ovariectomized rats. In the third lumbar spine, comparable improvements in trabecular thickness and bone volume were also noted. In addition, EGCG treatment increased the bone volume in the tibial cortex. Increased BMP-2 expression may be one of the effective mechanisms for EGCG. No significant systemic toxic effect after EGCG treatment was found in the serial biochemistry data [94]. In male rats, Shen et al. found that GTP supplementation $(0.5 \% w / v$ in potable water) ameliorated trabecular and cortical bone loss. A dual effect of GTP was identified through enhanced bone formation and declined bone resorption via GTP's antioxidant capacity [88]. Chen's team evaluated the effect of EGCG in vivo in male rats via local injection at a low dose. Lin et al. found that percutaneous local injection of EGCG for 2 weeks, $10 \mu \mathrm{M} / \mathrm{L}, 40 \mu \mathrm{L}$, enhances callus bone volume and increases the tibial mechanical properties. The break load, maximal load, Young's modulus, and stiffness improved after EGCG treatment with more BMP-2 expression than that found in male rats without EGCG treatment in a tibia fracture model [95]. Lin et al. also demonstrated that local EGCG $(10 \mu \mathrm{M} / \mathrm{L}, 40 \mu \mathrm{L})$ improves femoral defect healing with de novo bone formation by enhancing the bone volume and improving the mechanical properties similar to the above study. With increased expression of BMP-2, EGCG enhanced de novo bone formation by improving max load, ultimate stress, max load, break point, break point, and stiffness [96].

EGCG has also been studied in glucocorticoid-induced osteoporosis (GIO). Xi et al. found EGCG injection $(0.5 \mathrm{mg} / \mathrm{kg} /$ day $)$ for 4 weeks improved the cancellous structure in proximal tibia metaphysis in GIO. EGCG reduced peroxisome proliferator-activated receptor $\gamma$ protein expression and enhanced $\beta$-catenin, Wnt, and cyclin D1 as part of the mechanism [91]. Liu et al. found EGCG pretreatment significantly protected osteoblast viability from exposure to dexamethasone (DEX). In addition, ALP and SOD activities and mineralization were also improved. In osteoblasts, promoting the nuclear factor erythroid-derived 2-like-2 (Nrf2) pathway at both the cellular and mitochondrial levels may be one of the mechanisms in EGCG that reduces DEX-induced ROS. EGCG also reduced osteoblast apoptosis and increased $11 \beta$-hydroxysteroid dehydrogenase activity. In the femora, EGCG improved bone microstructure and ameliorated deterioration of bone quality induced by DEX [97].

Shen's team also evaluated the effects of GTP in a systemic chronic inflammation lipopolysaccharide (LPS)-induced bone loss model of adult rats. GTP at $0.5 \% w / v$ for 12 weeks led to higher values of BMD, bone mineral content (BMC), and serum osteocalcin, but decreased serum TRAP. GTP was shown to increase bone strength by attenuating oxidative stress-induced damage and inflammation [98,99]. Moreover, there was a synergistic osteoprotective effect of GTP and alfacalcidol on bone properties as shown by an increased bone mass, restored LPS-induced deleterious effects in the femur, proximal tibia and endocortical tibial shaft, maintained bone microarchitecture and femoral strength, and decreased serum TRAP on LPS-induced bone loss model [100]. Such synergistic effects are mediated through the suppression of 8-hydroxy-2'-deoxyguanosine and tibia mRNA expression of tumor necrosis factor- $\alpha$ (TNF- $\alpha$ ) induced by LPS in urine [100].

Shen et al. found GTP use decreased fat-free mass and ameliorated bone properties via improving bone microarchitecture, BMD, and strength in obese rats in a high-fat diet-induced bone deterioration model. Effects of GTP were brought forth through suppression of bone remodeling, leading to greater bone volume [101,102]. The bone-protective effects of GTP are similar in obese rats before and after switching to a caloric-restricted diet. Common effects of GTP included increased femoral trabecular thickness and number, mass and strength, and cortical thickness of tibia, as well as decreased insulin-like growth factor-I and leptin. EGCG also attenuated formation rate, trabecular separation, and eroded surface at proximal tibia [89]. Shen et al. demonstrated the beneficial effects of GTP on bone formation at both lumbar vertebrae and femur in high-fat diet and caloric-restricted diet models [89].

In the model of periodontal disease, the protective effects of GTP on alveolar bone have also been extensively studied. Nakamura et al. demonstrated oral green tea catechins attenuated LPS-induced alveolar bone loss in BALB/c mice by reducing IL-1 $\beta$ production or by directly decreasing osteoclastogenesis [103]. Yoshinaga et al. found that green tea extract decreased inflammatory cell 
infiltration and RANKL expression, eventually leading to loss of alveolar bone resorption in a rat model [104]. Cai et al. found 0.02\% EGCG in drinking water reduced bone loss in a rat model of experimental periodontitis. EGCG can reduce inflammatory serum mediators by decreasing IL-1 $\beta$, TNF- $\alpha$, IL-17, IL-6, and other mediators, but not IL-23 [105].

Gennaro et al. found that green tea treatment decreased TNF- $\alpha$ expression in periodontal disease and ameliorated alveolar bone resorption in diabetic rats [106]. Jin et al. found EGCG prohibited titanium particle-induced osteolysis by inhibiting TNF- $\alpha$ expression and osteoclast formation [107]. Almeida et al. found that topical green tea extract solution (GTE) decreased inflammatory process including decreasing TNF- $\alpha$ and IL-1 $\beta$ while increasing IL-10 in experimental periodontitis. Moreover, fewer TRAP-positive multinucleated osteoclasts and higher bone in furcation were found with GTE treatment [46].

A high dose of GTE may actually harm bones by acting as a pro-oxidant. Iwaniec et al. found that green tea extract ( $1 \%$ and $2 \%, w / w$ in diet) for 6 weeks was harmful to bone growth in growing male mice, with reduced cortical bone volume and thickness, shorter bone length, and compromised BMC [108] (Table 2).

Table 2. In vivo effects of catechins.

\begin{tabular}{|c|c|c|}
\hline First Author, Year & Experimental Design and Treatments & Results \\
\hline Shen, 2008 [86] & $\begin{array}{l}\text { Model: a mouse model of OVX-induced bone loss } \\
\text { 14-mo-old female rats }(n=10 / \text { group) } \\
\text { Treatments: A } 16 \text {-week study of a } 2 \text { (SHAM vs. OVX) } \times 3 \\
\text { (no GTP, } 0.1 \% \text { GTP, and } 0.5 \% \text { GTP in drinking water) } \\
\text { factorial design }\end{array}$ & $\begin{array}{l}\leftrightarrow \text { femur bone mineral density between baseline and the } \\
\text { SHAM+0.5\% GTP group. } \\
\text { In OVX group: } \\
\downarrow \text { liver glutathione peroxidase activity, serum estradiol, } \\
\text { and bone mineral density group. } \\
\text { GTP supplementation: } \\
\uparrow \text { urinary epigallocatechin and epicatechin concentrations, } \\
\text { liver glutathione peroxidase activity, and femur bone mineral } \\
\text { density decreased urinary 8-hydroxy-2'-deoxyguanosine and } \\
\text { urinary calcium levels. } \\
\leftrightarrow \text { serum estradiol and blood chemistry levels. }\end{array}$ \\
\hline Iwaniec, 2009 [108] & $\begin{array}{l}\text { Model: a mouse model of obese } \\
\text { Male leptin-deficient (ob/ob) obese mice and male C57Bl/6 WT } \\
\text { littermates (4-week-old) } \\
\text { Treatments: Each group had equal numbers of obese and } \\
\text { lean mice. Groups included 0\% GTE (control), 1\% GTE, and 2\% } \\
\text { GTE for } 6 \mathrm{w}\end{array}$ & $\begin{array}{l}\text { Compared to control group, GTE groups: } \\
\text { Neither genotype affected femoral bone mineral density } \\
\downarrow \text { femur length, volume, mineral content, cortical volume, } \\
\text { cortical thickness, cancellous bone volume/tissue volume, } \\
\text { and trabecular thickness in lumbar vertebrae in GTE groups. }\end{array}$ \\
\hline Shen, 2010 [98] & $\begin{array}{l}\text { Model: a mouse model of LPS-induced chronic inflammation } \\
\text { and bone loss } \\
\text { Virgin CD female rats ( } 3 \text { months old) } \\
\text { Treatments: placebo implantation (P), lipopolysaccharide (LPS) } \\
\text { administration (L), P+0.5\% GTP (PG) and LPS }+0.5 \% \text { GTP (LG) } \\
\text { for } 12 \text { w } \\
2 \text { (placebo vs. LPS administration) } \times 2 \text { (no GTP vs. } 0.5 \% \text { GTP in } \\
\text { drinking water) factorial design }\end{array}$ & $\begin{array}{l}\text { Neither LPS administration nor GTP levels affected body } \\
\text { weight and femoral bone area throughout the study period. } \\
\text { LPS administration: } \\
\downarrow \text { femur BMC and BMD, and serum OC levels } \\
\uparrow \text { serum TRAP, urinary 8-OHdG, and spleen mRNA expression } \\
\text { of TNF- } \alpha \text { and COX-2 levels } \\
\text { GTP supplementation: } \\
\uparrow \text { values for femur BMC, BMD, and serum OC } \\
\downarrow \text { values for serum TRAP, urinary 8-OHdG, and spleen mRNA } \\
\text { expression of TNF- } \alpha \text { and COX-2 levels }\end{array}$ \\
\hline
\end{tabular}


Table 2. em Cont.

\begin{tabular}{|c|c|c|}
\hline First Author, Year & Experimental Design and Treatments & Results \\
\hline Shen, 2011 [99] & $\begin{array}{l}\text { Model: a mouse model of LPS-induced chronic inflammation } \\
\text { and bone loss } \\
\text { 3-month-old virgin Sprague Dawley (SD) female rats } \\
\text { Treatments: placebo implantation (P), lipopolysaccharide (LPS) } \\
\text { administration (L), P+0.5\% GTP (PG), or LPS }+0.5 \% \text { GTP (LG) } \\
\text { for } 12 \mathrm{w} \\
2 \text { (placebo vs. LPS administration) } \times 2 \text { (no GTP vs. } 0.5 \% \text { GTP in } \\
\text { drinking water) factorial design }\end{array}$ & $\begin{array}{l}\text { LPS group: } \\
\downarrow \text { trabecular volume fraction, thickness, and bone formation in } \\
\text { proximal tibia } \\
\uparrow \text { osteoclast number and surface perimeter in proximal tibia and } \\
\text { eroded surface in endocortical tibial shafts } \\
\text { GTP group: } \\
\uparrow \text { trabecular volume fraction and number in both femur and } \\
\text { tibia and periosteal bone formation rate in tibial shafts } \\
\downarrow \text { trabecular separation in proximal tibia and eroded surface in } \\
\text { endocortical tibial shafts } \\
\uparrow \text { strength of femur } \\
\downarrow \text { TNF- } \alpha \text { expression in tibia }\end{array}$ \\
\hline Shen, 2011 [109] & $\begin{array}{l}\text { Model: a mouse model of LPS-induced chronic inflammation } \\
\text { Virgin CD female rats ( } 3 \text { months old) } \\
\text { Treatments: (1) LPS administration (L, } n=10),(2) \text { LPS + } \\
\text { 1- } \alpha \text {-OH-vitamin D3 (LD, } n=10),(3) \text { LPS + GTP (LG, } n=10), \\
\text { and (4) LPS + GTP + 1- } \alpha \text {-OH-vitamin D3 (LGD, } n=10) \text { for } 12 \mathrm{w}\end{array}$ & $\begin{array}{l}\text { Compared to LPS group, Both GTP and alfacalcidol: } \\
\uparrow \text { femoral mass, trabecular volume, thickness, and number in } \\
\text { proximal tibia and femur, and periosteal bone formation rate in } \\
\text { tibial shafts } \\
\downarrow \text { trabecular separation and osteoclast number in proximal tibia } \\
\text { and eroded surface in endocortical tibial shafts } \\
\uparrow \text { femoral strength } \\
\downarrow \text { TNF- } \alpha \text { expression in proximal tibia }\end{array}$ \\
\hline Oka, 2012 [54] & $\begin{array}{l}\text { Model: cultures of rat osteoclast precursors cells and } \\
\text { mature osteoclasts } \\
\text { Treatments: the black tea polyphenol, } \\
\text { theaflavin-3,3'-digallate (TFDG), or EGCG }(10 \text { and } 100 \mu \mathrm{M}) \\
\text { was added }\end{array}$ & $\begin{array}{l}\text { Compared to control group, TFDG or EGCG treatment: } \\
\downarrow \text { numbers of multinucleated osteoclasts and actin rings } \\
\downarrow \text { MMP-2 and MMP-9 activities } \\
\downarrow \text { MMP-9 mRNA levels }\end{array}$ \\
\hline
\end{tabular}

Model: a mouse model of high-fat (HF) diet-induced

obese female

3-month-old Sprague Dawley female rats

Shen 2012 [101] Treatments: After low-fat (LF) $(10 \%$ energy as fat) $(n=12)$ or HF

diet ( $45 \%$ energy as fat) $(n=24)$ ad libitum for $4 \mathrm{~m}$, whereas those in the HF diet group were randomly divided into two groups: with (the HF + GTP group, $n=12$ ) or without GTP (HF group, $n=12$ ) in drinking water, in addition to an HF diet for another $4 \mathrm{~m}$

Model: a mouse model of OVX-induced bone loss

Twelve-week-old female Sprague-Dawley rats

Treatments: (1) sham-operated controls (SHAM; $n=8) ;(2) \quad \uparrow$ bone volume, trabecular thickness, trabecular numbness, and

ovariectomized controls $(\mathrm{OVX} ; n=14) ;(3)$ OVX with EGCG 0.34 $\mathrm{mg} / \mathrm{kg} /$ day $(\mathrm{OVX}+1$ EGCG; $n=12$; estimated peak serum concentration, $1 \mu \mathrm{M})$; and (4) OVX with EGCG $3.4 \mathrm{mg} / \mathrm{kg} / \mathrm{day}$ $(\mathrm{OVX}+10$ EGCG; $\mathrm{n}=14$; estimated peak serum concentration, $10 \mu \mathrm{M})$. Three months after OVX, EGCG was given intraperitoneally for $12 \mathrm{w}$

Compared to HF group, GTP supplementation:

$\uparrow$ percentage of fat-free mass, bone mineral density

and strength, and GPX protein expression

$\downarrow$ percentage of fat mass, serum insulin-like growth factor I,

leptin, adiponectin, and proinflammatory cytokines in the obese rats

trabecular separation.

Similar $\uparrow$ in bone volume and trabecular thickness in third lumbar spine.

$\uparrow$ bone volume in tibial cortex

$\uparrow$ trabecular number and trabecular volume in histology

\begin{tabular}{|c|c|c|}
\hline Shen, 2013 [102] & $\begin{array}{l}\text { Model: a mouse model of high-fat diet (HFD)-induced obese } \\
\text { female 3-month-old virgin Sprague-Dawley female rats } \\
\text { Treatments: After } 4 \mathrm{~m} \text { of HF diet, they were randomly divided } \\
\text { into two groups, with GTP supplement in drinking water } \\
\text { (the HFD + GTP group, } n=12 \text { ) or without GTP (the HFD group, } \\
n=12 \text { ), in addition to the same HFD for another } 4 \mathrm{~m}\end{array}$ & $\begin{array}{l}\text { Compared to HF group, GTP supplementation: } \\
\uparrow \text { BMD at the femur, a greater trabecular volume, thickness, and } \\
\text { number at the proximal tibia, a larger cortical area and } \\
\text { thickness at the tibial shaft, and a greater trabecular volume } \\
\text { and thickness at the femur and the lumbar vertebrae } \\
\downarrow T b . S p, \text { MAR, bone formation rate, and eroded surface at } \\
\text { the tibia }\end{array}$ \\
\hline Yoshinaga, 2014 [104] & $\begin{array}{l}\text { Model: a mouse model of LPS-induced PE } \\
\text { 9-week-old male Lewis rats } \\
\text { Treatments: LPS group }(n=12) \text {; the green tea extract } \\
\text { group ( }(n=12) ; \text { and the phosphate buffered saline (PBS) group } \\
(n=6) \text { for } 20 \mathrm{~d}\end{array}$ & $\begin{array}{l}\text { Compared to LPS group, GTE group: } \\
\downarrow \text { loss of attachment, level of alveolar bone, inflammatory cell } \\
\text { infiltration and RANKL expression }\end{array}$ \\
\hline Cai, 2015 [105] & $\begin{array}{l}\text { Model: a mouse PE model induced by P. gingivalis infection } \\
\text { Female BALB/c mice ( } 8 \text {-w-old) } \\
\text { Treatments: EGCG group }(0.02 \%) \text { or drinking water group both } \\
\text { infected with } P \text {. gingivalis every } 2 \text { days for } 15 \mathrm{w}\end{array}$ & $\begin{array}{l}\text { Compared to water group, EGCG group: } \\
\downarrow \text { reduction in bone loss } \\
\downarrow \text { inflammatory serum mediators } \\
\downarrow \text { high positive areas of IL-17 and IL-1 } \beta \\
\downarrow \text { IL- } 1 \beta, \text { IL- } 6 \text {, IL-17, TNF- } \alpha \text {, and other mediators, but not IL-23 }\end{array}$ \\
\hline Gennaro, 2015 [106] & $\begin{array}{l}\text { Model: a mouse models of type } 1 \text { diabetes } \\
\text { Male Wistar rats (8-10-w-old) } \\
\text { Treatments: Groups included the Diab group (type } 1 \text { diabetes) } \\
\text { and Ctr (control group). Each group was further divided into } \\
\text { two control groups (water and green tea-treated) and two } \\
\text { diabetic groups (water and green-tea treated) measured at } 15,30 \text {, } \\
60 \text {, and } 90 \mathrm{~d}\end{array}$ & $\begin{array}{l}\downarrow \text { number of cells expressing RANKL and TNF- } \alpha \text { in diabetic } \\
\text { rats treated with green tea. } \\
\uparrow \text { cells positive for OPG, RUNX-2, and IL-10 in diabetic rats }\end{array}$ \\
\hline
\end{tabular}


Table 2. em Cont.

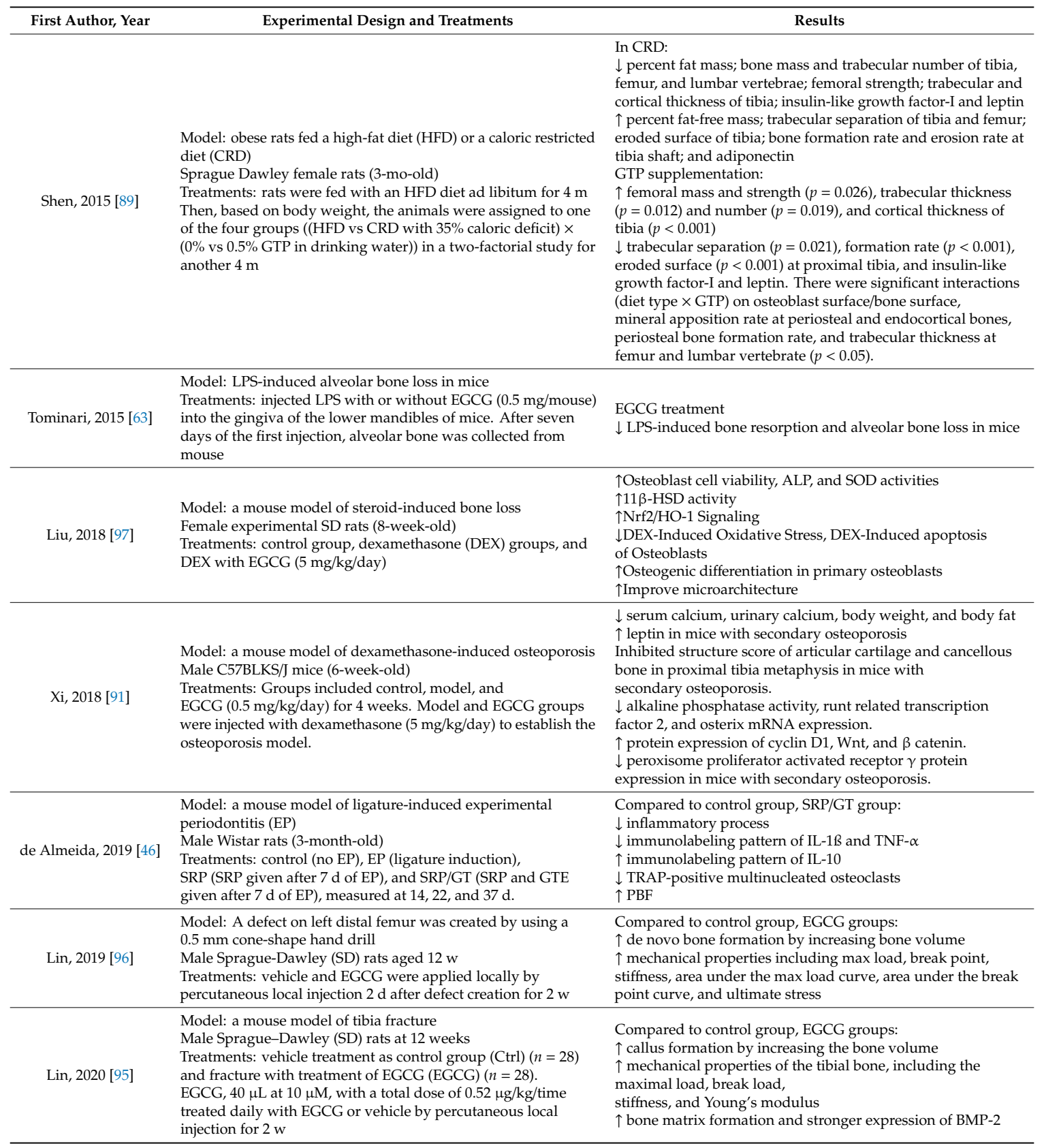

ALP, alkaline phosphatase; BMD, Bone mineral density; BMP-2, Bone Morphogenetic Protein 2; BR, buckling ratio; COX, cyclooxygenase; EGCG, epigallocatechin gallate; FHP, free hydroxyproline; GAG, glycosaminoglycan; GT, green tea; GTE, green tea extract; GTP, green tea polyphenols; iNOS, inducible nitric oxide synthase; IL-1 $\beta$, interleukin-1 $\beta$; LPS, lipopolysaccharide; MREI, molar roots exposure index; NANA, N-acetylneuraminic acid; NF- $\mathrm{KB}$, nuclear factor kappa-B; NO, nitric oxide; RANKL, Receptor activator of nuclear factor kappa-B ligand; RUNX2, Runt-related transcription factor 2; OPG, osteoprotegerin; OVX, ovariectomized; SG, salivary glands;

TC, Tai Chi; TNF- $\alpha$, tumor necrosis factor- $\alpha ; \uparrow$, increase; $\downarrow$, decrease; $\leftrightarrow$, no change.

\subsection{Human Studies of Catechins}

\subsubsection{Epidemiological Observational Studies}

The diagnostic criteria of osteoporosis were set by the standard deviation (SD) scores of BMD related to the peak bone mass in healthy young women. Osteoporosis is defined as a T score of -2.5 or less in BMD, and low bone mass (osteopenia) is stated as having a BMD T-score between -1 and -2.5 [110]. Hip fractures and vertebral fractures are prototypical osteoporotic fractures and 
intensely associated with reductions in hip and spine BMD [111]. Since BMD is the golden standard for osteoporosis diagnosis, following up on the effects of tea on BMD is required for evaluating the potential application of tea on osteoporosis prevention. Currently, overall bone strength cannot be measured precisely; thus, BMD is widely used as a proxy for bone strength, as BMD accounts for about $70 \%$ of bone strength. BMD is highly correlated with bone strength and is one of the best predictors for osteoporotic fracture [1,112]. In clinical practice, we use dual-energy X-ray absorptiometry (DXA) to quantify BMD at the central skeleton including the femoral neck, spine, and hip [113]. BMD can be used to predict fracture risk, monitor the disease progression or monitor response to osteoporosis medication two years after the inception of therapies [114-118]. Bone turnover markers (BTMs) can be effective tools to evaluate therapy short-term due to the limited availability, cost, and inconvenience of DXA and the delay in detecting BMD changes after treatment initiation. Serum C-terminal telopeptide of type 1 collagen (CTX) and procollagen type $1 \mathrm{~N}$ propeptide (P1NP) are good tools for short-term monitoring to evaluate the responses to osteoporosis treatment and can be the base for appropriately adjusting treatment regimens earlier than BMD [119], but not associated with hip fracture risk [120].

Several epidemiological observational studies reported the bone health promoting effects of tea. Habitual tea drinkers with higher BMD have been reported among post-menopausal women in the United Kingdom [121], Canada [122], and the United States [123], as well as among both men and women in Taiwan [124]. Other studies also verified the protection effect of tea from hip fracture [125,126].

The effectiveness of tea on fracture reduction was first reported on 1995 [125]. A total of 5618 women aged 50 years older living in Europe were enrolled in the Mediterranean Osteoporosis (MEDOS) Study to observe the risk factors for hip fracture. In all tea-drinking countries, a significant lower risk for hip fracture was observed [125]. The MEDOS Study enrolled 730 men with hip fracture in Europe. Drinking tea showed a $28 \%$ decrease in the risk of hip fracture [126].

In addition to fracture reduction, the association between BMD and tea drinking has been previously reported. Hoover et al. reported tea drinkers have higher lumbar and femoral BMDs and lean body mass in 62 postmenopausal women in Canada [122]. In a study on 1256 post-menopausal women in the United Kingdom, Hegarty et al. found drinking tea is associated with higher BMD at the lumbar spine and Ward's triangle without affecting the femoral neck [121]. Similarly, 47,720 women aged 45-58 years participated in the Danish Osteoporosis Prevention Study (DOPS). The results indicated a protective effect of tea drinking in those with T-scores above -0.75 in the femoral neck [127]. Wu et al. reported an epidemiological survey on 497 men and 540 women in Taiwan. Tea drinkers were found to have higher lumbar BMD, while the duration of tea usage was the only independent factor for BMD [124]. Hossein-Nezhad et al. reported that female tea drinkers that consumed five cups or more daily had higher BMD in the hip among 830 men and women (20-76 years old) living in Iran [128]. In an investigation of the prevalence of postmenopausal osteoporosis in Turkey (IPPOT Study), 742 women were included in the study. Hamdi Kara et al. reported a higher T-score in BMD in those who drink tea [129]. Muraki et al. reported that BMD was higher in subjects with tea-drinking habits in a cross-sectional study of 632 women older than 60 years [130]. In a study with 354 subjects (151 normal and 203 osteoporotic) from India, drinking seven cups or more of tea per day was found to be a protective factor from osteoporosis [131].

There are several prospective studies regarding tea and BMDs. A four-year cross-sectional and prospective longitudinal study consisting of 1500 women aged 70-85 years in Australia found that tea drinkers had higher total hip BMD in the cross-sectional analysis and less total hip BMD loss in the prospective analysis [132]. In a prospective cohort study in Australia with 1188 women aged 75 years and older, Myers et al. showed that in senile women with high fracture risk, higher intake of some flavonoids and black tea can lower the risk of major osteoporotic and hip fracture-related hospitalization [133]. In the Women's Health Initiative Observational Study with a multiethnic postmenopausal cohort $(n=91,465)$, tea consumption was associated with increased total body BMD. However, the fracture risk at the wrist and hip was not reduced by tea consumption [123]. Tavani et al. compared 279 women in Italy with hip fracture and 1061 controls. They found no effect of tea drinking 
on reducing the hip fracture risk after adjusting for the confounding factors including age, education, smoking status, menopausal status, total alcohol drinking, and calcium intake [134].

On the contrary, several studies could not show tea to be effective for BMD improvement or fracture reduction. In a case-control study examining 277 controls, 154 wrist fracture patients, and 102 hip fracture patients in Canadian women (50-84 years), there was no correlation between tea consumption and fracture risk [135]. In 703 unrelated elderly older than 90 years and 581 pairs of controls and hip fracture incident patients ( $71 \pm 7$ years) in China, there was no relationship between tea consumption and fracture risk $[136,137]$. On the contrary, tea drinkers showed greater hip fracture risk (OR 22.8; 95\% CI 3.73 to 139.43) in a case-controlled study in an Indian urban population [138]. In a cross-sectional study with 1495 Chinese women, 1.9\% higher BMD and 3.6\% lower buckling ratio were found in tea drinkers $(n=732)$ compared to non-tea drinkers $(n=763)$. The results indicated that tea drinking enhanced bone strength in Chinese women [139]. The China Kadoorie Biobank (CKB) included 453,625 participants. Daily tea drinkers had lower risk of fracture (hazard ratio (HR): 0.88). Green tea drinkers (HR: 0.80) and those who had drank tea for 30 years or longer (HR: 0.68) had a reduced risk of hip fracture [140]. In a sub-analysis of CKB, 20,643 participants who finished a baseline survey (2004-2008) and re-survey (2013-2014) were included. Prolonged weekly tea consumption in women, but not men, was shown to result in higher BMD in calcaneus measures [141].

\subsubsection{Human Clinical Trials}

Two randomized control trials were found. Shen et al. conducted a 6-month randomized placebo-controlled trial to evaluated the effects of green tea and Tai Chi (TC) on bone health in 171 postmenopausal osteopenia women. They found significant increases in BAP level and BAP/TRAP ratio due to GTP intake (at 1 month) and TC (at 3 months). At the end of study, muscle strength was significantly improved by GTP, TC, and GTP + TC interventions. There was no effect of GTP and TC on serum TRAP, serum and urinary calcium, and inorganic phosphate [142,143]. Improvement of muscle strength may decrease falls and eventually reduce fractures. Similar to the previous animal study, there was a significant reduction of urinary $8-\mathrm{OHdG}$, an oxidative DNA damage biomarker, concentrations in all three treated groups at 3 months and 6 months [144].

The Minnesota Green Tea Trial was a 12-month randomized, double-blind, placebo-controlled clinical trial with 937 50-70 years old postmenopausal women to treated placebo or GTE containing 843 mg (-)-epigallocatechin-3-gallate [145,146]. The effect of BMD was analyzed in a subgroup 121 high body mass index (BMI) (BMI $\geq 25.0$ ) individuals. The differences in changes in percentage of body fat, total fat mass, BMI, or BMD over 12 months between 60 taking a placebo and 61 women taking GTE were not significant. In participants with higher BMI, GTE reduced gynoid and tissue fat percentage. There were no changes in circulating ghrelin, insulin, adiponectin, or leptin concentrations [147] (Table 3; Figure 1).

Table 3. Human effects of catechins.

\begin{tabular}{|c|c|c|}
\hline First Author, Year & Experimental Design and Treatments & Results \\
\hline Kreiger, 1992 [135] & $\begin{array}{l}\text { Model: a case-control study examined the effect of diet on the } \\
\text { risk of postmenopausal fracture of the hip and wrist. } \\
\text { Treatments: Cases, women aged 50-84 y, were admitted to one } \\
\text { of four Metropolitan Toronto hospitals during the period } \\
\text { September } 1983 \text { through May } 1985 \text {. } \\
\text { Controls were women of the same age, admitted to the } \\
\text { same hospitals, and seen for orthopedic or general } \\
\text { surgical complaints. }\end{array}$ & $\begin{array}{l}\text { Coffee and tea consumption appeared to be unrelated to } \\
\text { fracture risk. }\end{array}$ \\
\hline
\end{tabular}


Table 3. em Cont.

\begin{tabular}{|c|c|c|}
\hline First Author, Year & Experimental Design and Treatments & Results \\
\hline Tavani, 1995 [134] & $\begin{array}{l}\text { Model: } 279 \text { cases of hip fracture and } 1061 \text { controls in hospital } \\
\text { for acute, nonneoplastic nontraumatic, } \\
\text { and non-hormone-related diseases } \\
\text { Treatments: consumption of coffee and other } \\
\text { methylxanthine-containing beverages }\end{array}$ & $\leftrightarrow$ hip fractures \\
\hline Hoover, 1996 [122] & $\begin{array}{l}\text { Model: Physical and lifestyle data were collected from } 62 \\
\text { postmenopausal women who had declined hormone } \\
\text { replacement therapy. } \\
\text { Treatments: Tea drinking was assessed by self-completed } \\
\text { questionnaire and women were categorized as tea drinkers or } \\
\text { non-tea drinkers. }\end{array}$ & $\begin{array}{l}\text { Compared to non-tea drinkers, tea drinkers: } \\
\uparrow \text { associated with both bone density } \\
\uparrow \text { femoral BMD, lumbar BMD, and lean body mass }\end{array}$ \\
\hline Kanis, 1999 [126] & $\begin{array}{l}\text { Model: a multicenter study to identify risk factors for hip } \\
\text { fracture in men aged } 50 \text { y or more. } \\
\text { Treatments: } 730 \text { men with hip fracture from } 14 \text { centers, and } 1132 \\
\text { age-stratified controls selected from the neighborhood or } \\
\text { population registers. questionnaire examined aspects of work, } \\
\text { physical activity past and present, diseases and drugs, height, } \\
\text { weight, indices of co-morbidity, and consumption of tobacco, } \\
\text { alcohol, calcium, coffee, and tea. }\end{array}$ & $\begin{array}{l}\text { Of the potentially 'reversible' risk factors, BMI, leisure exercise, } \\
\text { exposure to sunlight, and consumption of tea and alcohol and } \\
\text { tobacco remained independent risk factors after multivariate } \\
\text { analysis, accounting for } 54 \% \text { of hip fractures }\end{array}$ \\
\hline $\begin{array}{c}\text { Vestergaard, } 2001 \\
{[127]}\end{array}$ & $\begin{array}{l}\text { Model: to predict spinal and femoral bone mineral density } \\
\text { (BMD) in perimenopausal women from simple clinical and } \\
\text { biochemical variables. } \\
\text { Treatments: } 2016 \text { women 3-24 months after last menstrual } \\
\text { bleeding. Mean age } 50.1 \pm 2.8 \text { years. Independent factors: age, } \\
\text { height, weight, number of full-term pregnancies, weekly hours } \\
\text { of physical activity, sunbathing habits, use of sun bed, } \\
\text { daily intake of calcium and vitamin D, smoking habits, } \\
\text { and consumption of alcohol, coffee, and tea. }\end{array}$ & $\begin{array}{l}\text { Conclusions: Simple clinical and biochemical variables are not } \\
\text { useful to predict spinal and femoral BMD in the individual } \\
\text { perimenopausal woman }\end{array}$ \\
\hline Devine, 2007 [132] & $\begin{array}{l}\text { Model: Using both cross-sectional and longitudinal study } \\
\text { designs, we examined the relation of tea consumption with } \\
\text { hip structure. } \\
\text { Treatments: Randomly selected women ( } n=1500 \text { ) aged } 70-85 \text { y } \\
\text { participated in a 5-y prospective trial to evaluate whether oral } \\
\text { calcium supplements prevent osteoporotic fractures. }\end{array}$ & $\begin{array}{l}\text { In the cross-sectional analysis, tea drinkers: } \\
\uparrow \text { total hip areal bone mineral density (aBMD) } \\
\text { In the prospective analysis over } 4 \text { y, tea drinkers: } \\
\downarrow \text { loss of total hip aBMD }\end{array}$ \\
\hline $\begin{array}{l}\text { Hossein-Nezhad, } \\
\quad 2007[128]\end{array}$ & $\begin{array}{l}\text { Model: BMD was measured at the lumbar spine and hip, in } 830 \\
\text { men and women living in Tehran, all aged between } 20 \text { and } 76 \mathrm{y} \text {. } \\
\text { Treatments: The degree of tea consumption was assessed by } \\
\text { questionnaire, and subjects were categorized as either tea } \\
\text { drinkers (more than five cups of tea per day) or non-tea drinkers } \\
\text { (equal to or less than five cups of tea per day) }\end{array}$ & $\begin{array}{l}\text { Compared to non-tea drinkers, tea drinkers: } \\
\uparrow \text { BMD in the hip of female tea drinkers }\end{array}$ \\
\hline $\begin{array}{c}\text { Hamdi Kara, } 2007 \\
\text { [129] }\end{array}$ & $\begin{array}{l}\text { Model: investigation of prevalence of postmenopausal } \\
\text { osteoporosis in Turkey (IPPOT Study) } \\
\text { Treatments: } 742 \text { women were included in the study. The mean } \\
\text { age was } 57.6 \pm 9.6 \mathrm{y} \text {, and mean age at natural menopause was } \\
46.4 \pm 5.6 \mathrm{y} \text {. A semi-structured questionnaire was completed by } \\
\text { face-to-face interview, consisting of closed- and open-ended } \\
\text { questions about demographic characteristics, nutritional status, } \\
\text { and habits with two or more choices as possible responses. }\end{array}$ & $\begin{array}{l}\text { Compared to non-tea drinkers, tea drinkers: } \\
\uparrow \mathrm{T} \text {-scores, and BMD }\end{array}$ \\
\hline
\end{tabular}


Table 3. em Cont.

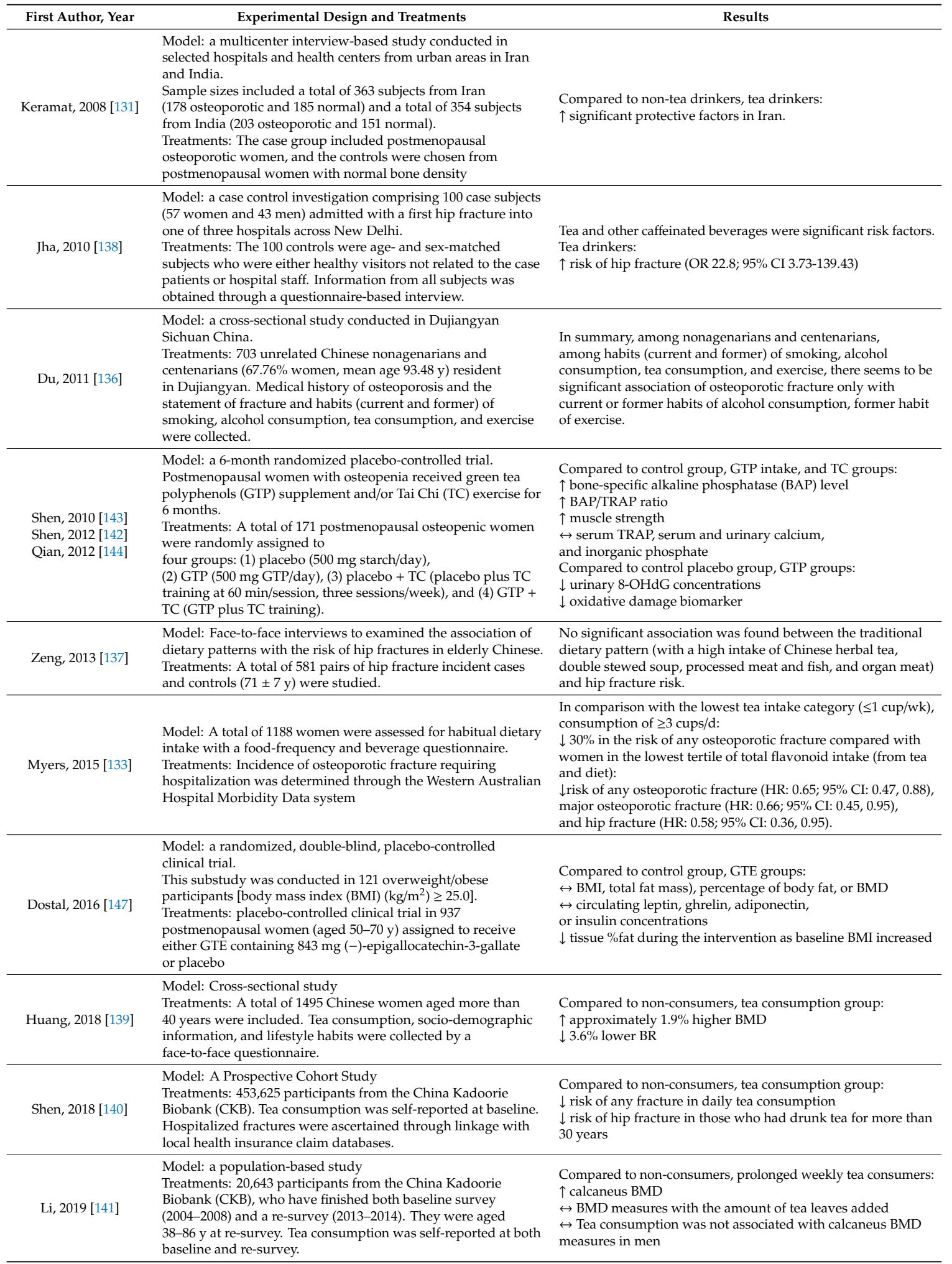

ALP, alkaline phosphatase; BMD, Bone mineral density; BMP-2, Bone Morphogenetic Protein 2; BR, buckling ratio;

COX, cyclooxygenase; EGCG, epigallocatechin gallate; FHP, free hydroxyproline; GAG, glycosaminoglycan;

GT, green tea; GTE, green tea extract; GTP, green tea polyphenols; iNOS, inducible nitric oxide synthase; IL-1 $\beta$, interleukin-1 $\beta$; LPS, lipopolysaccharide; MREI, molar roots exposure index; NANA, N-acetylneuraminic acid; NF- $\mathrm{kB}$, nuclear factor kappa-B; NO, nitric oxide; RANKL, Receptor activator of nuclear factor kappa-B ligand; RUNX2, Runt-related transcription factor 2; OPG, osteoprotegerin; OVX, ovariectomized; SG, salivary glands; TC, Tai Chi; TNF- $\alpha$, tumor necrosis factor- $\alpha$; $\uparrow$, increase; $\downarrow$, decrease; $\leftrightarrow$, no change. 


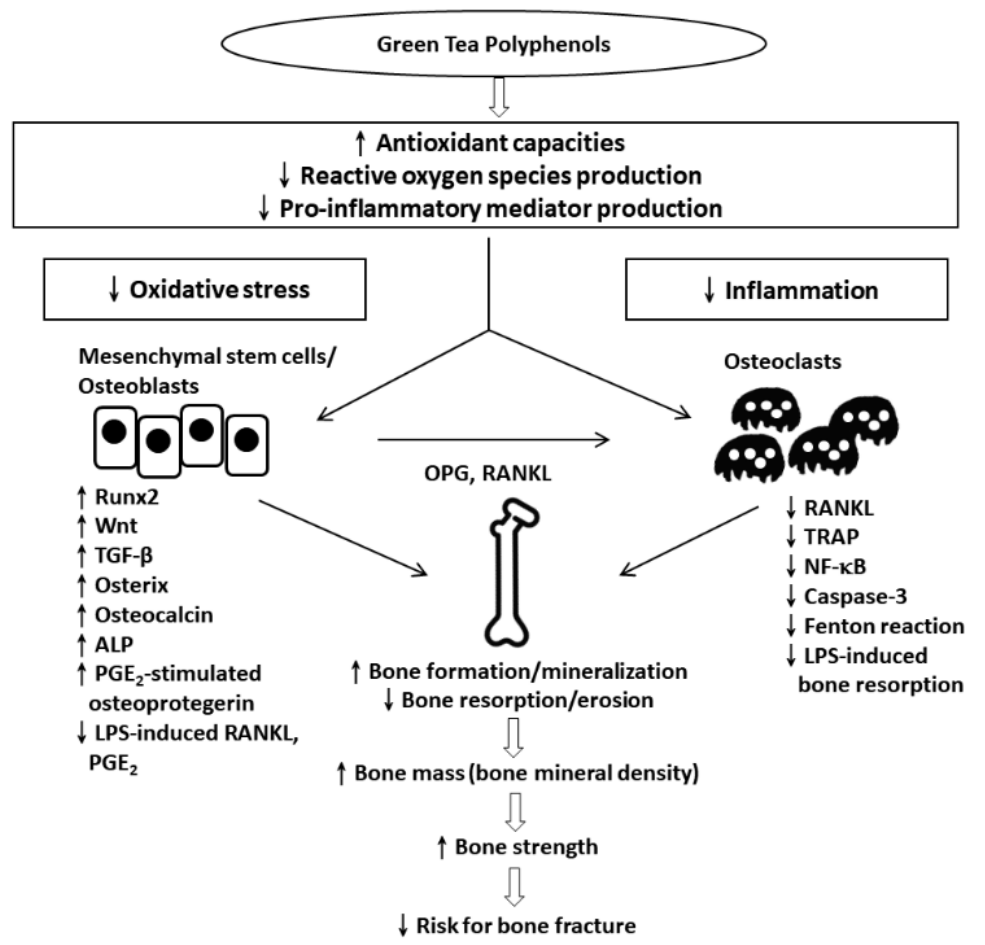

Figure 1. Summarized mechanisms of green tea polyphenols (GTP) in bone protection. Green tea catechins increase antioxidant capacities, reduce oxidative stress, and suppress the production of pro-inflammatory mediators. In osteoblasts, GTP inhibits oxidative stress by the upregulation of Runx2, Wnt, TGF- $\beta$, Osterix, Osteocalcin, and ALP. Moreover, RANKL, TRAP, and NF-kB activities are downregulated and caspase- 3 and Fenton reaction activities are upregulated in osteoclasts by GTP treatment. These actions should contribute to enhance bone formation/mineralization, and reduce bone resorption/erosion, resulting in increased bone mass, bone mineral density, and bone strength, leading to a reduced risk of bone fracture. ALP, alkaline phosphatase; GPX, glutathione peroxidase; NF- $\kappa B$, nuclear transcription factor- $\mathrm{B}$; PGE2, prostaglandin E2; RANKL, receptor activator of nuclear transcription factor- $\mathrm{KB}$ ligand; Run $\times 2$, Runt-related transcription factor 2 ; SOD, superoxide dismutase; TGF- $\beta$, transforming growth factor $\beta$; TRAP, tartrate-resistant acid phosphatase; $\uparrow$, upregulated; $\downarrow$, downregulated.

\section{Conclusions and Prospective}

Osteoporotic fractures may cause morbidity and even mortality in the elderly [148-152]. Among osteoporotic fracture, hip fracture usually leads to hospitalization, disability, and even death [153-156]. Though there are considerable advances in the fracture risk assessment and the improvement of medication to decrease the risk of fragility fracture, many people with high fracture risk do not receive adequate investigation and treatment. Osteoporosis treatment takes a life-long effort. For treatment with bisphosphonates, oral forms may cause upper gastrointestinal adverse reactions and intravenous forms may lead to acute phase reaction, both of which are common. An atypical femoral shaft or subtrochanteric fractures and osteonecrosis of the jaw are rare adverse effects of bisphosphonates and RANKL inhibitors [157]. Vasomotor symptoms, muscle cramps, and venous thrombosis are adverse effects related to selective estrogen receptor modulators. Elevated urine or serum calcium, or higher serum uric acid or muscle cramps, are adverse effects related to parathyroid hormone receptor agonists $[158,159]$. Due to the long-term nature of osteoporosis treatment, many individuals fear adverse effects from the medications above. Thus, an agent that promotes bone health may be beneficial to individuals with osteoporosis, especially for senile patients.

GTE has been shown to have bone health-promoting effects in the studies reviewed in this paper. Improvement in muscle function may also contribute to fracture reduction, though many 
obstacles still exist in efficiently applying GTE as a nutrient to protect bone or prevent fracture. First, bioactive ingredients vary between studies, depending on the origin of tea, time of harvest, method of tea preparation and preservation, the batch of tea, stability of bioactive ingredients, and the route of administration in humans. These obstacles make it difficult to standardize bioactive ingredients. Therefore, it is almost impossible to repeat studies even in the same center once the same batch of bioactive ingredients runs out. This difficulty can be observed by the low number of randomized control trials published (two). In the two randomized control trials, only BMD or bone markers results were reported, and no data on fractures. In most phase III trials of currently available anti-osteoporotic drugs, sample sizes consist of several thousand subjects. If we want to test the efficacy of GTE in preventing fracture, at least ten thousand more subjects may be required, as well as the financial support of government or big pharmaceutical companies. Thus, a more cost-effective, alternative approach is required to test the efficacy of nutrients in preventing fracture.

The Minnesota Green Tea Trial is a well-focused trial because only EGCG was used. Capsule EGCG also simplifies the bioactive ingredients. Since EGCG is very unstable, it is important to protect its bioactivity in capsule form. Treatment duration is also important. In the Minnesota Green Tea Trial, treatment duration was only one year. Though many anti-osteoporotic medications show great efficacy in reducing fracture one year after treatment, it is not easy for naturally-derived nutrients to achieve similar effects to clinical drugs. Dose is also an important issue. In the Minnesota Green Tea Trial, 800 mg EGCG daily was used for one year. It is unknown whether this dose is suitable for protecting bone health. Since both anabolic and anti-catabolic effects of EGCG were found in MSC and stromal cells [37,39-41,56-58], pre-osteoclasts may be the target cells of EGCG. The anti-catabolic effects of EGCG can vary depending on the MSC/stromal cell regulation of osteoclastogenesis at lower concentrations, or on the direct inhibition of osteoclastogenesis at higher concentrations.

Even though randomized control trials did not show that GTE provides anti-fracture efficacy, safety data in the trials are promising. With the current safety data available, GTE should be relatively safe for promoting bone health. More longitudinal studies are required to prove its safety for long-term use. On the basis of the currently available results, other results that are related to bone health, such as quality of life, balance, function, and mobility, may be a good alternative way to evaluate the beneficial effects of GTE. Due to limited of catechins in human data on BMD and anti-fracture efficacy, a large-scale, long-term, placebo-controlled randomized trial with a tea intervention of optimal duration is required for determining anti-fracture efficacy.

Author Contributions: Conceptualization, H.-T.H., T.-L.C., C.-H.C. and C.-L.S.; methodology, H.-T.H., T.-L.C., S.-Y.L., C.-J.H. and J.Y.C.; software, S.-Y.L., C.-J.H. and J.Y.C.; validation, H.-T.H., T.-L.C., S.-Y.L., C.-J.H., J.Y.C., R.-S.Y., C.-H.C. and C.-L.S.; formal analysis, H.-T.H., T.-L.C., S.-Y.L. and C.-H.C.; investigation, H.-T.H., T.-L.C., S.-Y.L., C.-J. H., J.Y.C., R.-S.Y., C.-H.C. and C.-L.S.; data curation, H.-T.H., T.-L.C., S.-Y.L., C.-J.H., J.Y.C., R.-S.Y., C.-H.C. and C.-L.S.; writing-original draft preparation, H.-T.H. and T.-L.C.; writing-review and editing, H.-T.H., T.-L.C., S.-Y.L., C.-J.H., J.Y.C., R.-S.Y., C.-H.C. and C.-L.S.; project administration, C.-H.C. and C.-L.S.; funding acquisition, C.-H.C. All authors have read and agreed to the published version of the manuscript.

Funding: This research received no external funding.

Acknowledgments: This study was supported in part by the National Health Research Institute (NHRI-EX101-9935EI) of Taiwan, Kaohsiung Medical University Hospital (KMUH-107-7R54), Kaohsiung Medical University (KMU-TC108A02-1, NCTUKMU108-BIO-04, NPUST-KMU-109-P002, and KMU-DK10500), Kaohsiung Municipal Ta-Tung Hospital (KMTTH107-26) and the Minister of Science and Technology of Taiwan (MOST 108-2314-B-037 -059-MY3). The funders had no role in the study design, data collection, and analysis, decision to publish, or preparation of the manuscript.

Conflicts of Interest: The authors declare that there is no conflict of interest.

\section{References}

1. Klibanski, A.; Adams-Campbell, L.; Bassford, T.L.; Blair, S.N.; Boden, S.D.; Dickersin, K.; Gifford, D.R.; Glasse, L.; Goldring, S.R.; Hruska, K.; et al. Osteoporosis prevention, diagnosis, and therapy. JAMA 2001, 285, 785-795. [CrossRef] [PubMed]

2. Kanis, J.A. Diagnosis of osteoporosis and assessment of fracture risk. Lancet 2002, 359, 1929-1936. [CrossRef] 
3. Osteoporosis Australia. Available online: http://www.osteoporosis.org.au (accessed on 20 July 2020).

4. Kanis, J.A.; Delmas, P.; Burckhardt, P.; Cooper, C.; Torgerson, D. Guidelines for diagnosis and management of osteoporosis. The European Foundation for Osteoporosis and Bone Disease. Osteoporos Int. 1997, 7, 390-406. [CrossRef] [PubMed]

5. Tatangelo, G.; Watts, J.; Lim, K.; Connaughton, C.; Abimanyi-Ochom, J.; Borgstrom, F.; Nicholson, G.C.; Shore-Lorenti, C.; Stuart, A.L.; Iuliano-Burns, S.; et al. The Cost of Osteoporosis, Osteopenia, and Associated Fractures in Australia in 2017. J. Bone Miner. Res. 2019, 34, 616-625. [CrossRef] [PubMed]

6. Ducy, P.; Schinke, T.; Karsenty, G. The osteoblast: A sophisticated fibroblast under central surveillance. Science 2000, 289, 1501-1504. [CrossRef] [PubMed]

7. Boyle, W.J.; Simonet, W.S.; Lacey, D.L. Osteoclast differentiation and activation. Nature 2003, 423, 337-342. [CrossRef]

8. Manolagas, S.C. Birth and Death of Bone Cells: Basic Regulatory Mechanisms and Implications for the Pathogenesis and Treatment of Osteoporosis*. Endocr. Rev. 2000, 21, 115-137. [CrossRef]

9. Harada, S.; Rodan, G.A. Control of osteoblast function and regulation of bone mass. Nature 2003, 423, 349-355. [CrossRef]

10. Ducy, P.; Zhang, R.; Geoffroy, V.; Ridall, A.L.; Karsenty, G. Osf2/Cbfa1: A transcriptional activator of osteoblast differentiation. Cell 1997, 89, 747-754. [CrossRef]

11. Nakashima, K.; Zhou, X.; Kunkel, G.; Zhang, Z.; Deng, J.M.; Behringer, R.R.; de Crombrugghe, B. The novel zinc finger-containing transcription factor osterix is required for osteoblast differentiation and bone formation. Cell 2002, 108, 17-29. [CrossRef]

12. DeLaurier, A.; Eames, B.F.; Blanco-Sánchez, B.; Peng, G.; He, X.; Swartz, M.E.; Ullmann, B.; Westerfield, M.; Kimmel, C.B. Zebrafish sp7:EGFP: A transgenic for studying otic vesicle formation, skeletogenesis, and bone regeneration. Genesis 2010, 48, 505-511. [CrossRef] [PubMed]

13. Corrado, A.; Cici, D.; Rotondo, C.; Maruotti, N.; Cantatore, F.P. Molecular Basis of Bone Aging. Int. J. Mol. Sci. 2020, 21, 3679. [CrossRef] [PubMed]

14. Almeida, M.; Han, L.; Martin-Millan, M.; Plotkin, L.I.; Stewart, S.A.; Roberson, P.K.; Kousteni, S.; O’Brien, C.A.; Bellido, T.; Parfitt, A.M.; et al. Skeletal involution by age-associated oxidative stress and its acceleration by loss of sex steroids. J. Biol. Chem. 2007, 282, 27285-27297. [CrossRef] [PubMed]

15. Zhou, Q.; Zhu, L.; Zhang, D.; Li, N.; Li, Q.; Dai, P.; Mao, Y.; Li, X.; Ma, J.; Huang, S. Oxidative Stress-Related Biomarkers in Postmenopausal Osteoporosis: A Systematic Review and Meta-Analyses. Dis. Markers 2016, 2016, 7067984. [CrossRef]

16. Domazetovic, V.; Marcucci, G.; Iantomasi, T.; Brandi, M.L.; Vincenzini, M.T. Oxidative stress in bone remodeling: Role of antioxidants. Clin. Cases Miner. Bone Metab. 2017, 14, 209-216. [CrossRef]

17. Manolagas, S.C.; Almeida, M. Gone with the Wnts: Beta-catenin, T-cell factor, forkhead box O, and oxidative stress in age-dependent diseases of bone, lipid, and glucose metabolism. Mol. Endocrinol. 2007, 21, 2605-2614. [CrossRef]

18. Komori, T. Cell Death in Chondrocytes, Osteoblasts, and Osteocytes. Int. J. Mol. Sci. 2016, 17, 2045. [CrossRef]

19. Cao, J.; Venton, L.; Sakata, T.; Halloran, B.P. Expression of RANKL and OPG correlates with age-related bone loss in male C57BL/6 mice. J. Bone Miner. Res. 2003, 18, 270-277. [CrossRef]

20. Cao, J.J.; Wronski, T.J.; Iwaniec, U.; Phleger, L.; Kurimoto, P.; Boudignon, B.; Halloran, B.P. Aging increases stromal/osteoblastic cell-induced osteoclastogenesis and alters the osteoclast precursor pool in the mouse. J. Bone Miner. Res. 2005, 20, 1659-1668. [CrossRef]

21. Shen, C.L.; Chyu, M.C. Tea flavonoids for bone health: From animals to humans. J. Investig. Med. 2016, 64, 1151-1157. [CrossRef]

22. Garrett, I.R.; Boyce, B.F.; Oreffo, R.O.; Bonewald, L.; Poser, J.; Mundy, G.R. Oxygen-derived free radicals stimulate osteoclastic bone resorption in rodent bone in vitro and in vivo. J. Clin. Invest. 1990, 85, 632-639. [CrossRef] [PubMed]

23. Banfi, G.; Iorio, E.L.; Corsi, M.M. Oxidative stress, free radicals and bone remodeling. Clin. Chem. Lab. Med. 2008, 46, 1550-1555. [CrossRef] [PubMed]

24. Nagaoka, M.; Maeda, T.; Chatani, M.; Handa, K.; Yamakawa, T.; Kiyohara, S.; Negishi-Koga, T.; Kato, Y.; Takami, M.; Niida, S.; et al. A Delphinidin-Enriched Maqui Berry Extract Improves Bone Metabolism and Protects against Bone Loss in Osteopenic Mouse Models. Antioxidants 2019, 8, 386. [CrossRef] [PubMed] 
25. Bai, X.C.; Lu, D.; Bai, J.; Zheng, H.; Ke, Z.Y.; Li, X.M.; Luo, S.Q. Oxidative stress inhibits osteoblastic differentiation of bone cells by ERK and NF-kappaB. Biochem. Biophys. Res. Commun. 2004, 314, 197-207. [CrossRef]

26. Manolagas, S.C. De-fense! De-fense! De-fense: Scavenging $\mathrm{H}_{2} \mathrm{O}_{2}$ while making cholesterol. Endocrinology 2008, 149, 3264-3266. [CrossRef]

27. Yang, S.; Madyastha, P.; Bingel, S.; Ries, W.; Key, L. A new superoxide-generating oxidase in murine osteoclasts. J. Biol. Chem. 2001, 276, 5452-5458. [CrossRef]

28. Kim, B.; Lee, S.H.; Song, S.J.; Kim, W.H.; Song, E.S.; Lee, J.C.; Lee, S.J.; Han, D.W.; Lee, J.H. Protective Effects of Melon Extracts on Bone Strength, Mineralization, and Metabolism in Rats with Ovariectomy-Induced Osteoporosis. Antioxidants 2019, 8, 306. [CrossRef]

29. Milkovic, L.; Vukovic, T.; Zarkovic, N.; Tatzber, F.; Bisenieks, E.; Kalme, Z.; Bruvere, I.; Ogle, Z.; Poikans, J.; Velena, A.; et al. Antioxidative 1,4-Dihydropyridine Derivatives Modulate Oxidative Stress and Growth of Human Osteoblast-Like Cells In Vitro. Antioxidants 2018, 7, 123. [CrossRef]

30. Oh, Y.; Ahn, C.B.; Cho, W.H.; Yoon, N.Y.; Je, J.Y. Anti-Osteoporotic Effects of Antioxidant Peptides PIISVYWK and FSVVPSPK from Mytilus edulis on Ovariectomized Mice. Antioxidants 2020, 9, 866. [CrossRef]

31. Domazetovic, V.; Marcucci, G.; Falsetti, I.; Bilia, A.R.; Vincenzini, M.T.; Brandi, M.L.; Iantomasi, T. Blueberry Juice Antioxidants Protect Osteogenic Activity against Oxidative Stress and Improve Long-Term Activation of the Mineralization Process in Human Osteoblast-Like SaOS-2 Cells: Involvement of SIRT1. Antioxidants 2020, 9, 125. [CrossRef]

32. Sanghani-Kerai, A.; Osagie-Clouard, L.; Blunn, G.; Coathup, M. The influence of age and osteoporosis on bone marrow stem cells from rats. Bone Jt. Res. 2018, 7, 289-297. [CrossRef] [PubMed]

33. Chen, H.T.; Lee, M.J.; Chen, C.H.; Chuang, S.C.; Chang, L.F.; Ho, M.L.; Hung, S.H.; Fu, Y.C.; Wang, Y.H.; Wang, H.I.; et al. Proliferation and differentiation potential of human adipose-derived mesenchymal stem cells isolated from elderly patients with osteoporotic fractures. J. Cell Mol. Med. 2012, 16, 582-593. [CrossRef] [PubMed]

34. Lee, M.J.; Chen, H.T.; Ho, M.L.; Chen, C.H.; Chuang, S.C.; Huang, S.C.; Fu, Y.C.; Wang, G.J.; Kang, L.; Chang, J.K. PPARgamma silencing enhances osteogenic differentiation of human adipose-derived mesenchymal stem cells. J. Cell Mol. Med. 2013, 17, 1188-1193. [CrossRef]

35. Tyner, S.D.; Venkatachalam, S.; Choi, J.; Jones, S.; Ghebranious, N.; Igelmann, H.; Lu, X.; Soron, G.; Cooper, B.; Brayton, C.; et al. p53 mutant mice that display early ageing-associated phenotypes. Nature 2002, 415, 45-53. [CrossRef] [PubMed]

36. Luk, H.Y.; Appell, C.; Chyu, M.C.; Chen, C.H.; Wang, C.Y.; Yang, R.S.; Shen, C.L. Impacts of Green Tea on Joint and Skeletal Muscle Health: Prospects of Translational Nutrition. Antioxidants 2020, 9, 50. [CrossRef] [PubMed]

37. Shen, C.L.; Chyu, M.C.; Wang, J.S. Tea and bone health: Steps forward in translational nutrition. Am. J. Clin. Nutr. 2013, 98, 1694S-1699S. [CrossRef] [PubMed]

38. Tang, G.Y.; Zhao, C.N.; Xu, X.Y.; Gan, R.Y.; Cao, S.Y.; Liu, Q.; Shang, A.; Mao, Q.Q.; Li, H.B. Phytochemical Composition and Antioxidant Capacity of 30 Chinese Teas. Antioxidants 2019, 8, 180. [CrossRef]

39. Liao, S.; Kao, Y.H.; Hiipakka, R.A. Green tea: Biochemical and biological basis for health benefits. Vitam. Horm. 2001, 62, 1-94.

40. Zhao, C.N.; Tang, G.Y.; Cao, S.Y.; Xu, X.Y.; Gan, R.Y.; Liu, Q.; Mao, Q.Q.; Shang, A.; Li, H.B. Phenolic Profiles and Antioxidant Activities of 30 Tea Infusions from Green, Black, Oolong, White, Yellow and Dark Teas. Antioxidants 2019, 8, 215. [CrossRef]

41. Katiyar, S.K.; Elmets, C.A. Green tea polyphenolic antioxidants and skin photoprotection (Review). Int. J. Oncol. 2001, 18, 1307-1313. [CrossRef]

42. Kondo, K.; Kurihara, M.; Fukuhara, K. Mechanism of antioxidant effect of catechins. Methods Enzymol. 2001, 335, 203-217. [PubMed]

43. Toronjo Urquiza, L.; James, D.C.; Nagy, T.; Falconer, R.J. Screening Naturally Occurring Phenolic Antioxidants for Their Suitability as Additives to CHO Cell Culture Media Used to Produce Monoclonal Antibodies. Antioxidants 2019, 8, 159. [CrossRef] [PubMed] 
44. Meneses-Gutierrez, C.L.; Hernandez-Damian, J.; Pedraza-Chaverri, J.; Guerrero-Legarreta, I.; Tellez, D.I.; Jaramillo-Flores, M.E. Antioxidant Capacity and Cytotoxic Effects of Catechins and Resveratrol Oligomers Produced by Enzymatic Oxidation against T24 Human Urinary Bladder Cancer Cells. Antioxidants 2019, 8, 214. [CrossRef] [PubMed]

45. Fang, X.; Azain, M.; Crowe-White, K.; Mumaw, J.; Grimes, J.A.; Schmiedt, C.; Barletta, M.; Rayalam, S.; Park, H.J. Effect of Acute Ingestion of Green Tea Extract and Lemon Juice on Oxidative Stress and Lipid Profile in Pigs Fed a High-Fat Diet. Antioxidants 2019, 8, 195. [CrossRef] [PubMed]

46. De Almeida, J.M.; Marques, B.M.; Novaes, V.C.N.; de Oliveira, F.L.P.; Matheus, H.R.; Fiorin, L.G.; Ervolino, E. Influence of adjuvant therapy with green tea extract in the treatment of experimental periodontitis. Arch. Oral Biol. 2019, 102, 65-73. [CrossRef] [PubMed]

47. Attanzio, A.; D'Anneo, A.; Pappalardo, F.; Bonina, F.P.; Livrea, M.A.; Allegra, M.; Tesoriere, L. Phenolic Composition of Hydrophilic Extract of Manna from Sicilian Fraxinus angustifolia Vahl and its Reducing, Antioxidant and Anti-Inflammatory Activity in Vitro. Antioxidants 2019, 8, 494. [CrossRef] [PubMed]

48. Cheaib, D.; El Darra, N.; Rajha, H.N.; El-Ghazzawi, I.; Mouneimne, Y.; Jammoul, A.; Maroun, R.G.; Louka, N. Study of the Selectivity and Bioactivity of Polyphenols Using Infrared Assisted Extraction from Apricot Pomace Compared to Conventional Methods. Antioxidants 2018, 7, 174. [CrossRef]

49. Rha, C.S.; Jung, Y.S.; Lee, J.D.; Jang, D.; Kim, M.S.; Lee, M.S.; Hong, Y.D.; Kim, D.O. Chemometric Analysis of Extracts and Fractions from Green, Oxidized, and Microbial Fermented Teas and Their Correlation to Potential Antioxidant and Anticancer Effects. Antioxidants 2020, 9, 1015. [CrossRef]

50. Lee, S.; Yu, J.S.; Phung, H.M.; Lee, J.G.; Kim, K.H.; Kang, K.S. Potential Anti-Skin Aging Effect of (-)-Catechin Isolated from the Root Bark of Ulmus davidiana var. japonica in Tumor Necrosis Factor-alpha-Stimulated Normal Human Dermal Fibroblasts. Antioxidants 2020, 9, 981. [CrossRef]

51. Kim, T.Y.; Leem, E.; Lee, J.M.; Kim, S.R. Control of Reactive Oxygen Species for the Prevention of Parkinson's Disease: The Possible Application of Flavonoids. Antioxidants 2020, 9, 583. [CrossRef]

52. Nakagawa, H.; Wachi, M.; Woo, J.T.; Kato, M.; Kasai, S.; Takahashi, F.; Lee, I.S.; Nagai, K. Fenton reaction is primarily involved in a mechanism of (-)-epigallocatechin-3-gallate to induce osteoclastic cell death. Biochem. Biophys. Res. Commun. 2002, 292, 94-101. [CrossRef] [PubMed]

53. Yun, J.H.; Pang, E.K.; Kim, C.S.; Yoo, Y.J.; Cho, K.S.; Chai, J.K.; Kim, C.K.; Choi, S.H. Inhibitory effects of green tea polyphenol (-)-epigallocatechin gallate on the expression of matrix metalloproteinase-9 and on the formation of osteoclasts. J. Periodontal. Res. 2004, 39, 300-307. [CrossRef] [PubMed]

54. Oka, Y.; Iwai, S.; Amano, H.; Irie, Y.; Yatomi, K.; Ryu, K.; Yamada, S.; Inagaki, K.; Oguchi, K. Tea polyphenols inhibit rat osteoclast formation and differentiation. J. Pharmacol. Sci. 2012, 118, 55-64. [CrossRef] [PubMed]

55. Tokuda, H.; Takai, S.; Hanai, Y.; Matsushima-Nishiwaki, R.; Hosoi, T.; Harada, A.; Ohta, T.; Kozawa, O. (-)-Epigallocatechin gallate suppresses endothelin-1-induced interleukin-6 synthesis in osteoblasts: Inhibition of p44/p42 MAP kinase activation. FEBS Lett. 2007, 581, 1311-1316. [CrossRef] [PubMed]

56. Tokuda, H.; Takai, S.; Matsushima-Nishiwaki, R.; Akamatsu, S.; Hanai, Y.; Hosoi, T.; Harada, A.; Ohta, T.; Kozawa, O. (-)-epigallocatechin gallate enhances prostaglandin F2alpha-induced VEGF synthesis via upregulating SAPK/JNK activation in osteoblasts. J. Cell Biochem. 2007, 100, 1146-1153. [CrossRef] [PubMed]

57. Morinobu, A.; Biao, W.; Tanaka, S.; Horiuchi, M.; Jun, L.; Tsuji, G.; Sakai, Y.; Kurosaka, M.; Kumagai, S. (-)-Epigallocatechin-3-gallate suppresses osteoclast differentiation and ameliorates experimental arthritis in mice. Arthritis Rheum. 2008, 58, 2012-2018. [CrossRef] [PubMed]

58. Lee, J.H.; Jin, H.; Shim, H.E.; Kim,H.N.; Ha, H.; Lee, Z.H. Epigallocatechin-3-gallate inhibits osteoclastogenesis by down-regulating c-Fos expression and suppressing the nuclear factor-kappaB signal. Mol. Pharmacol. 2010, 77, 17-25. [CrossRef]

59. Lin, R.; Chen, C.; Wang, Y.; Ho, M.; Hung, S.; Chen, I.; Wang, G. (-)-Epigallocatechin gallate inhibition of osteoclastic differentiation via NF-kappaB. Biochem. Biophys. Res. Commun. 2009, 379, 1033-1037. [CrossRef]

60. Chen, C.H.; Ho, M.L.; Chang, J.K.; Hung, S.H.; Huang, H.T.; Wang, C.; Yeh, C.H.; Wang, G.J. Green tea catechins enhance the expression of osteoprotegerin(OPG) in pluripotent stem cells. J. Orthop Surg Taiwan 2003, 20, 178-183.

61. Chen, S.T.; Kang, L.; Wang, C.Z.; Huang, P.J.; Huang, H.T.; Lin, S.Y.; Chou, S.H.; Lu, C.C.; Shen, P.C.; Lin, Y.S.; et al. (-)-Epigallocatechin-3-Gallate Decreases Osteoclastogenesis via Modulation of RANKL and Osteoprotegrin. Molecules 2019, 24, 156. [CrossRef] 
62. Kuroyanagi, G.; Tokuda, H.; Yamamoto, N.; Kainuma, S.; Fujita, K.; Ohguchi, R.; Kawabata, T.; Sakai, G.; Matsushima-Nishiwaki, R.; Harada, A.; et al. (-)-Epigallocatechin gallate synergistically potentiates prostaglandin E(2)-stimulated osteoprotegerin synthesis in osteoblasts. Prostaglandins Other Lipid Mediat. 2017, 128-129, 27-33. [CrossRef] [PubMed]

63. Tominari, T.; Matsumoto, C.; Watanabe, K.; Hirata, M.; Grundler, F.M.; Miyaura, C.; Inada, M. Epigallocatechin gallate (EGCG) suppresses lipopolysaccharide-induced inflammatory bone resorption, and protects against alveolar bone loss in mice. FEBS Open Bio. 2015, 5, 522-527. [CrossRef] [PubMed]

64. Chen, C.H.; Ho, M.L.; Chang, J.K.; Hung, S.H.; Wang, G.J. Green tea catechin enhances osteogenesis in a bone marrow mesenchymal stem cell line. Osteoporos Int. 2005, 16, 2039-2045. [CrossRef] [PubMed]

65. Lin, S.Y.; Kang, L.; Wang, C.Z.; Huang, H.H.; Cheng, T.L.; Huang, H.T.; Lee, M.J.; Lin, Y.S.; Ho, M.L.; Wang, G.J.; et al. (-)-Epigallocatechin-3-Gallate (EGCG) Enhances Osteogenic Differentiation of Human Bone Marrow Mesenchymal Stem Cells. Molecules 2018, 23, 3221. [CrossRef] [PubMed]

66. Takai, S.; Matsushima-Nishiwaki, R.; Adachi, S.; Natsume, H.; Minamitani, C.; Mizutani, J.; Otsuka, T.; Tokuda, H.; Kozawa, O. (-)-Epigallocatechin gallate reduces platelet-derived growth factor-BB-stimulated interleukin-6 synthesis in osteoblasts: Suppression of SAPK/JNK. Mediators Inflamm. 2008, 2008, 291808. [CrossRef]

67. Vali, B.; Rao, L.G.; El-Sohemy, A. Epigallocatechin-3-gallate increases the formation of mineralized bone nodules by human osteoblast-like cells. J. Nutr. Biochem. 2007, 18, 341-347. [CrossRef]

68. Rawadi, G. Wnt signaling and potential applications in bone diseases. Curr. Drug Targets 2008, 9, 581-590. [CrossRef]

69. Matsuno, M.; Kozawa, O.; Suzuki, A.; Tokuda, H.; Kaida, T.; Matsuno, H.; Niwa, M.; Uematsu, T. Involvement of protein kinase $\mathrm{C}$ activation in endothelin-1-induced secretion of interleukin-6 in osteoblast-like cells. Cell Signal. 1998, 10, 107-111. [CrossRef]

70. Tokuda, H.; Takai, S.; Hanai, Y.; Matsushima-Nishiwaki, R.; Yamauchi, J.; Harada, A.; Hosoi, T.; Ohta, T.; Kozawa, O. (-)-Epigallocatechin gallate inhibits basic fibroblast growth factor-stimulated interleukin-6 synthesis in osteoblasts. Horm. Metab. Res. 2008, 40, 674-678. [CrossRef]

71. Hayashi, K.; Takai, S.; Matsushima-Nishiwaki, R.; Hanai, Y.; Kato, K.; Tokuda, H.; Kozawa, O. (-)-Epigallocatechin gallate reduces transforming growth factor beta-stimulated HSP27 induction through the suppression of stress-activated protein kinase/c-Jun N-terminal kinase in osteoblasts. Life Sci. 2008, 82, 1012-1017. [CrossRef]

72. Lu, T.X.; Rothenberg, M.E. MicroRNA. J. Allergy Clin. Immunol. 2018, 141, 1202-1207. [CrossRef] [PubMed]

73. Feurer, E.; Kan, C.; Croset, M.; Sornay-Rendu, E.; Chapurlat, R. Lack of Association Between Select Circulating miRNAs and Bone Mass, Turnover, and Fractures: Data From the OFELY Cohort. J. Bone Miner. Res. 2019, 34, 1074-1085. [CrossRef] [PubMed]

74. Hadjiargyrou, M.; Komatsu, D.E. The Therapeutic Potential of MicroRNAs as Orthobiologics for Skeletal Fractures. J. Bone Miner. Res. 2019, 34, 797-809. [CrossRef] [PubMed]

75. Zhang, J.; Hao, X.; Yin, M.; Xu, T.; Guo, F. Long non-coding RNA in osteogenesis: A new world to be explored. Bone Jt. Res. 2019, 8, 73-80. [CrossRef] [PubMed]

76. Takahara, S.; Lee, S.Y.; Iwakura, T.; Oe, K.; Fukui, T.; Okumachi, E.; Waki, T.; Arakura, M.; Sakai, Y.; Nishida, K.; et al. Altered expression of microRNA during fracture healing in diabetic rats. Bone Jt. Res. 2018, 7, 139-147. [CrossRef] [PubMed]

77. Kelch, S.; Balmayor, E.R.; Seeliger, C.; Vester, H.; Kirschke, J.S.; van Griensven, M. miRNAs in bone tissue correlate to bone mineral density and circulating miRNAs are gender independent in osteoporotic patients. Sci. Rep. 2017, 7, 15861. [CrossRef]

78. Chen, J.; Li, K.; Pang, Q.; Yang, C.; Zhang, H.; Wu, F.; Cao, H.; Liu, H.; Wan, Y.; Xia, W.; et al. Identification of suitable reference gene and biomarkers of serum miRNAs for osteoporosis. Sci. Rep. 2016, 6, 36347. [CrossRef]

79. Qiu, Y.; Chen, Y.; Zeng, T.; Guo, W.; Zhou, W.; Yang, X. EGCG ameliorates the hypoxia-induced apoptosis and osteogenic differentiation reduction of mesenchymal stem cells via upregulating miR-210. Mol. Biol. Rep. 2016, 43, 183-193. [CrossRef]

80. Rao, N.C.; Barsky, S.H.; Terranova, V.P.; Liotta, L.A. Isolation of a tumor cell laminin receptor. Biochem. Biophys. Res. Commun. 1983, 111, 804-808. [CrossRef] 
81. Malinoff, H.L.; Wicha, M.S. Isolation of a cell surface receptor protein for laminin from murine fibrosarcoma cells. J. Cell Biol. 1983, 96, 1475-1479. [CrossRef]

82. Lesot, H.; Kuhl, U.; Mark, K. Isolation of a laminin-binding protein from muscle cell membranes. EMBO J. 1983, 2, 861-865. [CrossRef] [PubMed]

83. Rao, C.N.; Castronovo, V.; Schmitt, M.C.; Wewer, U.M.; Claysmith, A.P.; Liotta, L.A.; Sobel, M.E. Evidence for a precursor of the high-affinity metastasis-associated murine laminin receptor. Biochemistry 1989, 28, 7476-7486. [CrossRef] [PubMed]

84. Tachibana, H.; Koga, K.; Fujimura, Y.; Yamada, K. A receptor for green tea polyphenol EGCG. Nat. Struct. Mol. Biol. 2004, 11, 380-381. [CrossRef]

85. Tachibana, H. Green tea polyphenol sensing. Proc. Jpn. Acad. Ser. B Phys. Biol. Sci. 2011, 87, 66-80. [CrossRef] [PubMed]

86. Shen, C.L.; Wang, P.; Guerrieri, J.; Yeh, J.K.; Wang, J.S. Protective effect of green tea polyphenols on bone loss in middle-aged female rats. Osteoporos Int. 2008, 19, 979-990. [CrossRef]

87. Shen, C.L.; Yeh, J.K.; Stoecker, B.J.; Chyu, M.C.; Wang, J.S. Green tea polyphenols mitigate deterioration of bone microarchitecture in middle-aged female rats. Bone 2009, 44, 684-690. [CrossRef]

88. Shen, C.L.; Cao, J.J.; Dagda, R.Y.; Tenner, T.E., Jr.; Chyu, M.C.; Yeh, J.K. Supplementation with green tea polyphenols improves bone microstructure and quality in aged, orchidectomized rats. Calcif. Tissue Int. 2011, 88, 455-463. [CrossRef]

89. Shen, C.L.; Han, J.; Wang, S.; Chung, E.; Chyu, M.C.; Cao, J.J. Green tea supplementation benefits body composition and improves bone properties in obese female rats fed with high-fat diet and caloric restricted diet. Nutr. Res. 2015, 35, 1095-1105. [CrossRef]

90. Cao, J.J. Effects of obesity on bone metabolism. J. Orthop Surg. Res. 2011, 6, 30. [CrossRef]

91. Xi, J.; Li, Q.; Luo, X.; Li, J.; Guo, L.; Xue, H.; Wu, G. Epigallocatechin-3-gallate protects against secondary osteoporosis in a mouse model via the Wnt/ß-catenin signaling pathway. Mol. Med. Rep. 2018, 18, 4555-4562. [CrossRef]

92. Smith, B.J.; Lerner, M.R.; Bu, S.Y.; Lucas, E.A.; Hanas, J.S.; Lightfoot, S.A.; Postier, R.G.; Bronze, M.S.; Brackett, D.J. Systemic bone loss and induction of coronary vessel disease in a rat model of chronic inflammation. Bone 2006, 38, 378-386. [CrossRef] [PubMed]

93. Hienz, S.A.; Paliwal, S.; Ivanovski, S. Mechanisms of Bone Resorption in Periodontitis. J. Immunol. Res. 2015, 2015, 615486. [CrossRef] [PubMed]

94. Chen, C.H.; Kang, L.; Lin, R.W.; Fu, Y.C.; Lin, Y.S.; Chang, J.K.; Chen, H.T.; Chen, C.H.; Lin, S.Y.; Wang, G.J.; et al. (-)-Epigallocatechin-3-gallate improves bone microarchitecture in ovariectomized rats. Menopause 2013, 20, 687-694. [CrossRef] [PubMed]

95. Lin, S.Y.; Kan, J.Y.; Lu, C.C.; Huang, H.H.; Cheng, T.L.; Huang, H.T.; Ho, C.J.; Lee, T.C.; Chuang, S.C.; Lin, Y.S.; et al. Green Tea Catechin (-)-Epigallocatechin-3-Gallate (EGCG) Facilitates Fracture Healing. Biomolecules 2020, 10, 620. [CrossRef] [PubMed]

96. Lin, S.Y.; Kang, L.; Chen, J.C.; Wang, C.Z.; Huang, H.H.; Lee, M.J.; Cheng, T.L.; Chang, C.F.; Lin, Y.S.; Chen, C.H. (-)-Epigallocatechin-3-gallate (EGCG) enhances healing of femoral bone defect. Phytomedicine 2019, 55, 165-171. [CrossRef] [PubMed]

97. Liu, S.; Yang, L.; Mu, S.; Fu, Q. Epigallocatechin-3-Gallate Ameliorates Glucocorticoid-Induced Osteoporosis of Rats in Vivo and in Vitro. Front. Pharmacol. 2018, 9, 447. [CrossRef] [PubMed]

98. Shen, C.L.; Yeh, J.K.; Cao, J.J.; Tatum, O.L.; Dagda, R.Y.; Wang, J.S. Green tea polyphenols mitigate bone loss of female rats in a chronic inflammation-induced bone loss model. J. Nutr. Biochem. 2010, 21, 968-974. [CrossRef]

99. Shen, C.L.; Yeh, J.K.; Samathanam, C.; Cao, J.J.; Stoecker, B.J.; Dagda, R.Y.; Chyu, M.C.; Dunn, D.M.; Wang, J.S. Green tea polyphenols attenuate deterioration of bone microarchitecture in female rats with systemic chronic inflammation. Osteoporos Int. 2011, 22, 327-337. [CrossRef]

100. Shen, C.L.; Yeh, J.K.; Cao, J.J.; Tatum, O.L.; Dagda, R.Y.; Wang, J.S. Synergistic effects of green tea polyphenols and alphacalcidol on chronic inflammation-induced bone loss in female rats. Osteoporos Int. 2010, 21, 1841-1852. [CrossRef]

101. Shen, C.L.; Cao, J.J.; Dagda, R.Y.; Chanjaplammootil, S.; Lu, C.; Chyu, M.C.; Gao, W.; Wang, J.S.; Yeh, J.K. Green tea polyphenols benefits body composition and improves bone quality in long-term high-fat diet-induced obese rats. Nutr. Res. 2012, 32, 448-457. [CrossRef] 
102. Shen, C.L.; Chyu, M.C.; Cao, J.J.; Yeh, J.K. Green tea polyphenols improve bone microarchitecture in high-fat-diet-induced obese female rats through suppressing bone formation and erosion. J. Med. Food 2013, 16, 421-427. [CrossRef] [PubMed]

103. Nakamura, H.; Ukai, T.; Yoshimura, A.; Kozuka, Y.; Yoshioka, H.; Yoshinaga, Y.; Abe, Y.; Hara, Y. Green tea catechin inhibits lipopolysaccharide-induced bone resorption in vivo. J. Periodontal. Res. 2010, 45, 23-30. [CrossRef] [PubMed]

104. Yoshinaga, Y.; Ukai, T.; Nakatsu, S.; Kuramoto, A.; Nagano, F.; Yoshinaga, M.; Montenegro, J.L.; Shiraishi, C.; Hara, Y. Green tea extract inhibits the onset of periodontal destruction in rat experimental periodontitis. J. Periodontal. Res. 2014, 49, 652-659. [CrossRef] [PubMed]

105. Cai, Y.; Chen, Z.; Liu, H.; Xuan, Y.; Wang, X.; Luan, Q. Green tea epigallocatechin-3-gallate alleviates Porphyromonas gingivalis-induced periodontitis in mice. Int. Immunopharmacol. 2015, 29, 839-845. [CrossRef] [PubMed]

106. Gennaro, G.; Claudino, M.; Cestari, T.M.; Ceolin, D.; Germino, P.; Garlet, G.P.; de Assis, G.F. Green Tea Modulates Cytokine Expression in the Periodontium and Attenuates Alveolar Bone Resorption in Type 1 Diabetic Rats. PLoS ONE 2015, 10, e0134784. [CrossRef] [PubMed]

107. Jin, S.; Park, J.Y.; Hong, J.M.; Kim, T.H.; Shin, H.I.; Park, E.K.; Kim, S.Y. Inhibitory effect of (-)-epigallocatechin gallate on titanium particle-induced TNF-alpha release and in vivo osteolysis. Exp. Mol. Med. 2011, 43, 411-418. [CrossRef] [PubMed]

108. Iwaniec, U.T.; Turner, R.T.; Koo, S.I.; Kaur, R.; Ho, E.; Wong, C.P.; Bruno, R.S. Consumption of green tea extract results in osteopenia in growing male mice. J. Nutr. 2009, 139, 1914-1919. [CrossRef]

109. Shen, C.L.; Yeh, J.K.; Samathanam, C.; Cao, J.J.; Stoecker, B.J.; Dagda, R.Y.; Chyu, M.C.; Wang, J.S. Protective actions of green tea polyphenols and alfacalcidol on bone microstructure in female rats with chronic inflammation. J. Nutr. Biochem. 2011, 22, 673-680. [CrossRef]

110. WHO Study Group. Assessment of fracture risk and its application to screening for postmenopausal osteoporosis. Report of a WHO Study Group. World Health Organ. Tech. Rep. Ser. 1994, 843, 1-129.

111. Marshall, D.; Johnell, O.; Wedel, H. Meta-analysis of how well measures of bone mineral density predict occurrence of osteoporotic fractures. BMJ 1996, 312, 1254-1259. [CrossRef]

112. Bouxsein, M.L.; Eastell, R.; Lui, L.Y.; Wu, L.A.; de Papp, A.E.; Grauer, A.; Marin, F.; Cauley, J.A.; Bauer, D.C.; Black, D.M.; et al. Change in Bone Density and Reduction in Fracture Risk: A Meta-Regression of Published Trials. J. Bone Miner. Res. 2019, 34, 632-642. [CrossRef] [PubMed]

113. Zeng, Q.; Li, N.; Wang, Q.; Feng, J.; Sun, D.; Zhang, Q.; Huang, J.; Wen, Q.; Hu, R.; Wang, L.; et al. The Prevalence of Osteoporosis in China, a Nationwide, Multicenter DXA Survey. J. Bone Miner. Res. 2019, 34, 1789-1797. [CrossRef] [PubMed]

114. Cummings, S.R.; Bates, D.; Black, D.M. Clinical use of bone densitometry: Scientific review. JAMA 2002, 288, 1889-1897. [CrossRef] [PubMed]

115. Anastasilakis, A.D.; Papapoulos, S.E.; Polyzos, S.A.; Appelman-Dijkstra, N.M.; Makras, P. Zoledronate for the Prevention of Bone Loss in Women Discontinuing Denosumab Treatment. A Prospective 2-Year Clinical Trial. J. Bone Miner. Res. 2019, 34, 2220-2228. [CrossRef] [PubMed]

116. Ferrari, S.; Libanati, C.; Lin, C.J.F.; Brown, J.P.; Cosman, F.; Czerwinski, E.; de Gregomicronrio, L.H.; Malouf-Sierra, J.; Reginster, J.Y.; Wang, A.; et al. Relationship Between Bone Mineral Density T-Score and Nonvertebral Fracture Risk Over 10 Years of Denosumab Treatment. J. Bone Miner. Res. 2019, 34, 1033-1040. [CrossRef]

117. Kim, T.Y.; Bauer, D.C.; McNabb, B.L.; Schafer, A.L.; Cosman, F.; Black, D.M.; Eastell, R. Comparison of BMD Changes and Bone Formation Marker Levels 3 Years After Bisphosphonate Discontinuation: FLEX and HORIZON-PFT Extension I Trials. J. Bone Miner. Res. 2019, 34, 810-816. [CrossRef]

118. Leder, B.Z.; Zapalowski, C.; Hu, M.Y.; Hattersley, G.; Lane, N.E.; Singer, A.J.; Dore, R.K. Fracture and Bone Mineral Density Response by Baseline Risk in Patients Treated With Abaloparatide Followed by Alendronate: Results From the Phase 3 ACTIVExtend Trial. J. Bone Miner. Res. 2019, 34, 2213-2219. [CrossRef]

119. Wu, C.H.; Chang, Y.F.; Chen, C.H.; Lewiecki, E.M.; Wüster, C.; Reid, I.; Tsai, K.S.; Matsumoto, T.; Mercado-Asis, L.B.; Chan, D.C.; et al. Consensus Statement on the Use of Bone Turnover Markers for Short-Term Monitoring of Osteoporosis Treatment in the Asia-Pacific Region. J. Clin. Densitom 2019. In press. [CrossRef] 
120. Crandall, C.J.; Vasan, S.; LaCroix, A.; LeBoff, M.S.; Cauley, J.A.; Robbins, J.A.; Jackson, R.D.; Bauer, D.C. Bone Turnover Markers Are Not Associated With Hip Fracture Risk: A Case-Control Study in the Women's Health Initiative. J. Bone Miner. Res. 2018, 33, 1199-1208. [CrossRef]

121. Hegarty, V.M.; May, H.M.; Khaw, K.T. Tea drinking and bone mineral density in older women. Am. J. Clin. Nutr. 2000, 71, 1003-1007. [CrossRef]

122. Hoover, P.A.; Webber, C.E.; Beaumont, L.F.; Blake, J.M. Postmenopausal bone mineral density: Relationship to calcium intake, calcium absorption, residual estrogen, body composition, and physical activity. Can. J. Physiol. Pharmacol. 1996, 74, 911-917. [CrossRef] [PubMed]

123. Chen, Z.; Pettinger, M.B.; Ritenbaugh, C.; LaCroix, A.Z.; Robbins, J.; Caan, B.J.; Barad, D.H.; Hakim, I.A. Habitual tea consumption and risk of osteoporosis: A prospective study in the women's health initiative observational cohort. Am. J. Epidemiol 2003, 158, 772-781. [CrossRef] [PubMed]

124. Wu, C.H.; Yang, Y.C.; Yao, W.J.; Lu, F.H.; Wu, J.S.; Chang, C.J. Epidemiological evidence of increased bone mineral density in habitual tea drinkers. Arch. Intern. Med. 2002, 162, 1001-1006. [CrossRef] [PubMed]

125. Johnell, O.; Gullberg, B.; Kanis, J.A.; Allander, E.; Elffors, L.; Dequeker, J.; Dilsen, G.; Gennari, C.; Lopes Vaz, A.; Lyritis, G.; et al. Risk factors for hip fracture in European women: The MEDOS Study. Mediterranean Osteoporosis Study. J. Bone Miner. Res. 1995, 10, 1802-1815. [CrossRef]

126. Kanis, J.; Johnell, O.; Gullberg, B.; Allander, E.; Elffors, L.; Ranstam, J.; Dequeker, J.; Dilsen, G.; Gennari, C.; Vaz, A.L.; et al. Risk factors for hip fracture in men from southern Europe: The MEDOS study. Mediterranean Osteoporosis Study. Osteoporos Int. 1999, 9, 45-54. [CrossRef]

127. Vestergaard, P.; Hermann, A.P.; Gram, J.; Jensen, L.B.; Eiken, P.; Abrahamsen, B.; Brot, C.; Kolthoff, N.; Sorensen, O.H.; Beck Nielsen, H.; et al. Evaluation of methods for prediction of bone mineral density by clinical and biochemical variables in perimenopausal women. Maturitas 2001, 40, 211-220. [CrossRef]

128. Hossein-nezhad, A.; Zh, M.; Shafaie, A.R.; Javadi, E.; Larijani, B. Relationship between Tea drinking and Bone Mineral Density in Iranian population. Iran. J. Public Health 2007, 36, 57-62.

129. Hamdi Kara, I.; Aydin, S.; Gemalmaz, A.; Akturk, Z.; Yaman, H.; Bozdemir, N.; Kurdak, H.; Sitmapinar, K.; Devran Sencar, I.; Basak, O.; et al. Habitual tea drinking and bone mineral density in postmenopausal Turkish women: Investigation of prevalence of postmenopausal osteoporosis in Turkey (IPPOT Study). Int. J. Vitam Nutr. Res. 2007, 77, 389-397. [CrossRef]

130. Muraki, S.; Yamamoto, S.; Ishibashi, H.; Oka, H.; Yoshimura, N.; Kawaguchi, H.; Nakamura, K. Diet and lifestyle associated with increased bone mineral density: Cross-sectional study of Japanese elderly women at an osteoporosis outpatient clinic. J. Orthop Sci. 2007, 12, 317-320. [CrossRef]

131. Keramat, A.; Patwardhan, B.; Larijani, B.; Chopra, A.; Mithal, A.; Chakravarty, D.; Adibi, H.; Khosravi, A. The assessment of osteoporosis risk factors in Iranian women compared with Indian women. BMC Musculoskelet Disord 2008, 9, 28. [CrossRef]

132. Devine, A.; Hodgson, J.M.; Dick, I.M.; Prince, R.L. Tea drinking is associated with benefits on bone density in older women. Am. J. Clin. Nutr. 2007, 86, 1243-1247. [CrossRef] [PubMed]

133. Myers, G.; Prince, R.L.; Kerr, D.A.; Devine, A.; Woodman, R.J.; Lewis, J.R.; Hodgson, J.M. Tea and flavonoid intake predict osteoporotic fracture risk in elderly Australian women: A prospective study. Am. J. Clin. Nutr. 2015, 102, 958-965. [CrossRef] [PubMed]

134. Tavani, A.; Negri, E.; La Vecchia, C. Coffee intake and risk of hip fracture in women in northern Italy. Prev. Med. 1995, 24, 396-400. [CrossRef] [PubMed]

135. Kreiger, N.; Gross, A.; Hunter, G. Dietary factors and fracture in postmenopausal women: A case-control study. Int. J. Epidemiol. 1992, 21, 953-958. [CrossRef] [PubMed]

136. Du, F.; Birong, D.; Changquan, H.; Hongmei, W.; Yanling, Z.; Wen, Z.; Li, L. Association of osteoporotic fracture with smoking, alcohol consumption, tea consumption and exercise among Chinese nonagenarians/centenarians. J. Nutr. Health Aging 2011, 15, 327-331. [CrossRef]

137. Zeng, F.F.; Wu, B.H.; Fan, F.; Xie, H.L.; Xue, W.Q.; Zhu, H.L.; Chen, Y.M. Dietary patterns and the risk of hip fractures in elderly Chinese: A matched case-control study. J. Clin. Endocrinol. Metab. 2013, 98, 2347-2355. [CrossRef]

138. Jha, R.M.; Mithal, A.; Malhotra, N.; Brown, E.M. Pilot case-control investigation of risk factors for hip fractures in the urban Indian population. BMC Musculoskelet Disord 2010, 11, 49. [CrossRef] 
139. Huang, H.; Han, G.Y.; Jing, L.P.; Chen, Z.Y.; Chen, Y.M.; Xiao, S.M. Tea Consumption Is Associated with Increased Bone Strength in Middle-Aged and Elderly Chinese Women. J. Nutr. Health Aging 2018, 22, $216-221$. [CrossRef]

140. Shen, Q.; Yu, C.; Guo, Y.; Bian, Z.; Zhu, N.; Yang, L.; Chen, Y.; Luo, G.; Li, J.; Qin, Y.; et al. Habitual Tea Consumption and Risk of Fracture in 0.5 Million Chinese Adults: A Prospective Cohort Study. Nutrients 2018, 10, 1633. [CrossRef]

141. Li, X.; Qiao, Y.; Yu, C.; Guo, Y.; Bian, Z.; Yang, L.; Chen, Y.; Yan, S.; Xie, X.; Huang, D.; et al. Tea consumption and bone health in Chinese adults: A population-based study. Osteoporos Int. 2019, 30, 333-341. [CrossRef]

142. Shen, C.L.; Chyu, M.C.; Yeh, J.K.; Zhang, Y.; Pence, B.C.; Felton, C.K.; Brismée, J.M.; Arjmandi, B.H.; Doctolero, S.; Wang, J.S. Effect of green tea and Tai Chi on bone health in postmenopausal osteopenic women: A 6-month randomized placebo-controlled trial. Osteoporos Int. 2012, 23, 1541-1552. [CrossRef] [PubMed]

143. Shen, C.L.; Chyu, M.C.; Pence, B.C.; Yeh, J.K.; Zhang, Y.; Felton, C.K.; Doctolero, S.; Wang, J.S. Green tea polyphenols supplementation and Tai Chi exercise for postmenopausal osteopenic women: Safety and quality of life report. BMC Complement. Altern Med. 2010, 10, 76. [CrossRef] [PubMed]

144. Qian, G.; Xue, K.; Tang, L.; Wang, F.; Song, X.; Chyu, M.C.; Pence, B.C.; Shen, C.L.; Wang, J.S. Mitigation of oxidative damage by green tea polyphenols and Tai Chi exercise in postmenopausal women with osteopenia. PLoS ONE 2012, 7, e48090. [CrossRef] [PubMed]

145. Samavat, H.; Dostal, A.M.; Wang, R.; Bedell, S.; Emory, T.H.; Ursin, G.; Torkelson, C.J.; Gross, M.D.; Le, C.T.; Yu, M.C.; et al. The Minnesota Green Tea Trial (MGTT), a randomized controlled trial of the efficacy of green tea extract on biomarkers of breast cancer risk: Study rationale, design, methods, and participant characteristics. Cancer Causes Control 2015, 26, 1405-1419. [CrossRef] [PubMed]

146. Dostal, A.M.; Samavat, H.; Bedell, S.; Torkelson, C.; Wang, R.; Swenson, K.; Le, C.; Wu, A.H.; Ursin, G.; Yuan, J.M.; et al. The safety of green tea extract supplementation in postmenopausal women at risk for breast cancer: Results of the Minnesota Green Tea Trial. Food Chem. Toxicol. 2015, 83, 26-35. [CrossRef]

147. Dostal, A.M.; Arikawa, A.; Espejo, L.; Kurzer, M.S. Long-Term Supplementation of Green Tea Extract Does Not Modify Adiposity or Bone Mineral Density in a Randomized Trial of Overweight and Obese Postmenopausal Women. J. Nutr. 2016, 146, 256-264. [CrossRef] [PubMed]

148. Chen, C.H.; Elsalmawy, A.H.; Ish-Shalom, S.; Lim, S.J.; Al-Ali, N.S.; Cunha-Borges, J.L.; Yang, H.; Casas, N.; Altan, L.; Moll, T.; et al. Study description and baseline characteristics of the population enrolled in a multinational, observational study of teriparatide in postmenopausal women with osteoporosis: The Asia and Latin America Fracture Observational Study (ALAFOS). Curr. Med. Res. Opin 2019, 35, 1041-1049. [CrossRef]

149. Chen, C.H.; Lim, S.J.; Oh, J.K.; Huang, T.W.; Zeng, Y.H.; Wu, M.T.; Yang, H.L.; Cheung, J.P.; Kim, J.W.; Han, J.H.; et al. Teriparatide in East Asian Postmenopausal Women with Osteoporosis in a Real-World Setting: A Baseline Analysis of the Asia and Latin America Fracture Observational Study (ALAFOS). Clin. Interv. Aging 2020, 15, 111-121. [CrossRef]

150. Wu, C.-H.; Hung, W.-C.; Chang, I.-L.; Tsai, T.-T.; Chang, Y.-F.; McCloskey, E.V.; Watts, N.B.; McClung, M.R.; Huang, C.-F.; Chen, C.-H.; et al. Pharmacologic intervention for prevention of fractures in osteopenic and osteoporotic postmenopausal women: Systemic review and meta-analysis. Bone Rep. 2020, 13, 100729. [CrossRef]

151. Bliuc, D.; Tran, T.; van Geel, T.; Adachi, J.D.; Berger, C.; van den Bergh, J.; Eisman, J.A.; Geusens, P.; Goltzman, D.; Hanley, D.A.; et al. Reduced Bone Loss Is Associated With Reduced Mortality Risk in Subjects Exposed to Nitrogen Bisphosphonates: A Mediation Analysis. J. Bone Miner. Res. 2019, 34, 2001-2011. [CrossRef]

152. Borhan, S.; Papaioannou, A.; Gajic-Veljanoski, O.; Kennedy, C.; Ioannidis, G.; Berger, C.; Goltzman, D.; Josse, R.; Kovacs, C.S.; Hanley, D.A.; et al. Incident Fragility Fractures Have a Long-Term Negative Impact on Health-Related Quality of Life of Older People: The Canadian Multicentre Osteoporosis Study. J. Bone Miner. Res. 2019, 34, 838-848. [CrossRef] [PubMed]

153. Chen, C.H.; Huang, P.J.; Huang, H.T.; Lin, S.Y.; Wang, H.Y.; Fang, T.J.; Lin, Y.C.; Ho, C.J.; Lee, T.C.; $\mathrm{Lu}$, Y.M.; et al. Impact of orthogeriatric care, comorbidity, and complication on 1-year mortality in surgical hip fracture patients: An observational study. Medicine 2019, 98, e17912. [CrossRef] [PubMed] 
154. Kjorholt, K.E.; Johnsen, S.P.; Kristensen, N.R.; Prieto-Alhambra, D.; Pedersen, A.B. Increasing Risk of Hospital-Treated Infections and Community-Based Antibiotic Use After Hip Fracture Surgery: A Nationwide Study 2005-2016. J. Bone Miner. Res. 2019, 34, 437-446. [CrossRef] [PubMed]

155. Diem, S.J.; Vo, T.N.; Langsetmo, L.; Schousboe, J.T.; Yaffe, K.; Ensrud, K.E.; Study of Osteoporotic Fractures Research, G. Impact of Competing Risk of Mortality on Association of Cognitive Impairment With Risk of Hip Fracture in Older Women. J. Bone Miner. Res. 2018, 33, 1595-1602. [CrossRef] [PubMed]

156. Parsons, N.; Griffin, X.L.; Achten, J.; Chesser, T.J.; Lamb, S.E.; Costa, M.L. Modelling and estimation of health-related quality of life after hip fracture: A re-analysis of data from a prospective cohort study. Bone Jt. Res. 2018, 7, 1-5. [CrossRef] [PubMed]

157. Leclerc, J.T.; Michou, L.; Vaillancourt, F.; Pelet, S.; Simonyan, D.; Belzile, E.L. Prevalence and Characteristics of Atypical Periprosthetic Femoral Fractures. J. Bone Miner. Res. 2019, 34, 83-92. [CrossRef] [PubMed]

158. Compston, J.E.; McClung, M.R.; Leslie, W.D. Osteoporosis. Lancet 2019, 393, 364-376. [CrossRef]

159. Paschalis, E.P.; Krege, J.H.; Gamsjaeger, S.; Eriksen, E.F.; Burr, D.B.; Disch, D.P.; Stepan, J.J.; Fahrleitner-Pammer, A.; Klaushofer, K.; Marin, F.; et al. Teriparatide Treatment Increases Mineral Content and Volume in Cortical and Trabecular Bone of Iliac Crest: A Comparison of Infrared Imaging With X-Ray-Based Bone Assessment Techniques. J. Bone Miner. Res. 2018, 33, 2230-2235. [CrossRef]

Publisher's Note: MDPI stays neutral with regard to jurisdictional claims in published maps and institutional affiliations.

(C) 2020 by the authors. Licensee MDPI, Basel, Switzerland. This article is an open access article distributed under the terms and conditions of the Creative Commons Attribution (CC BY) license (http://creativecommons.org/licenses/by/4.0/). 